\title{
Planejamento estratégico participativo para construir o destino turístico de Foz do Iguaçu - PR
}

\author{
José Manoel G. Gândara, Carlos Eduardo Chiquim, \\ Gabriel Palumbo e Henrique Lago
}

RESUMO

O trabalho presente tem como objetivo traçar um diagnóstico do turismo na região, devido às incertezas apuradas pela iniciativa privada local. Baseado neste diagnóstico da situação real do turismo da região, utilizando pesquisas documentais e também entrevistas em profundidade com atores sociais, foi possível identificar a real situação do segmento e traçar perspectivas a médio e longo prazo utilizando-se de propostas hierarquizadas com a participação da iniciativa pública, privada e representantes de entidades de classe do turismo na região.

\section{PALAVRAS CHAVE}

Diagnóstico; Planejamento Estratégico/Participativo; Turismo Sustentável; Foz do Iguaçu. 


\title{
Planeamiento estratégico participativo para construir el destino turístico del Santuario de Iguazu
}

\author{
José Manoel G. Gândara, Carlos Eduardo Chiquim, \\ Gabriel Palumbo e Henrique Lago
}

RESUMEN

El presente trabajo tiene como objetivo remontar un diagnostico del turismo en la región, derivado de las incertidumbres refinadas para la iniciativa privada local. Basado en este diagnostico de la situación verdadera del turismo de la región, la investigación se realizó a través de entrevistas documentales en profundidad con los agentes sociales, en este proceso se vio la posibilidad de identificar la situación verdadera del segmento turístico y remontar perspectivas del medio y funcionamiento que jerarquizo las ofertas con la participación de la iniciativa pública, privada y el representante de entidades de la sala de clase del turismo en la región.

PALABRAS CLAVE

Diagnóstico; Planteamiento Estratégico/Participativo; Turismo Sustentable; Santuario de Iguazu 


\section{INTRODUÇÃO}

Ao apresentar o trabalho "Planejamento Estratégico participativo para construir o destino turístico de Foz do Iguaçu - PR", é fundamental ter claro que o mesmo deve ser considerado como o início de um processo de mudanças. E por que mudanças são necessárias?

Pela importância de se ter bem clara a visão de o que a região quer para o seu futuro e de o que é preciso fazer para construir o futuro que se quer, tendo sempre presente as necessidades atuais, pois seria uma inconseqüência não pensar desta forma, mas principalmente, trabalhando estratégias para chegar onde se almeja. Sem iniciar o construir do amanhã que se quer corre-se o risco de que o futuro seja o resultado de não assumir as responsabilidades no presente. E como começar estas mudanças?

Através de um diagnóstico construído a partir de uma metodologia estratégico/participativa, que teve por objetivo produzir um material que efetivamente refletisse a realidade turística da região e as opiniões da comunidade local, buscando socializar informações para facilitar a tomada de decisões, tanto da iniciativa pública como da iniciativa privada e garantir o comprometimento de todos os envolvidos na produção deste documento na utilização do mesmo como um instrumento para iniciar as mudanças necessárias. E isto é suficiente?

Aofinal deste trabalhoforam estabelecidas, deforma estratégico/participativa, ações prioritárias que deixam clara a necessidade de continuidade do mesmo, tanto nas áreas de governança e qualidade quanto na área de marketing. Assumir a realidade é um passo importante, mas o caminho trilhado demonstrou claramente que sem se definir o futuro que se quer e efetivamente construí-lo estará se perdendo, mais uma vez, uma grande oportunidade de modificar os rumos do desenvolvimento.

Acreditamos que "CONSTRUINDO O DESTINO QUE QUEREMOS" éa única forma de, ao assumir as responsabilidades individuais e coletivas, a comunidade local construa, para o seu futuro, uma sociedade melhor, tendo a atividade turística como instrumento. 


\section{INICIO DE UM PROCESSO DE MUDANÇA}

Todo processo de planejamento e/ou reestruturação de um destino turístico deve iniciar-se com um diagnóstico, pois antes de resolver um problema é necessário identificar as características que o envolvem e a importância das mesmas. Para um adequado diagnóstico de um destino turístico, como destacado anteriormente, inicio do processo de planejamento do mesmo, é necessária participação de todo os atores sociais envolvidos na atividade turística, sempre considerando o conceito que todos devem partilhar os benefícios e responsabilidades. Contar com o apoio dos distintos atores sociais é imprescindível para o sucesso deste tipo de empreitada. Com isto se consegue mais facilmente a aceitação e a integração da sociedade nos projetos de sustentabilidade. "O desenvolvimento e a implementação dos objetivos estratégicos que buscam satisfazer os desejos dos turistas e as necessidades da comunidade local, dependem da boa relação entre os atores envolvidos nos processos turísticos" (Bigné, Font y Andreu, 507:2000).

Um dos elementos fundamentais para esta análise é a "compreensão dos "produtos principais" e os "produtos complementares" que compõem a oferta. Os produtos principais correspondem diretamente à experiência buscada por um grupo determinado e os produtos complementares ajudam a conformar uma oferta auto-suficiente, a fixar a identidade do destino e ampliar o leque de sensações a serviço da experiência buscada. Cada um deles pode se tornar por sua vez em um novo produto principal ao mesmo tempo em que servirá para rentabilizar os periféricos, gerar novos negócios e melhorar em geral o destino. Quanto mais elementos complementares, maiores são as chances do destino fidelizar clientes e atrair novos públicos que poderão usufruir do destino em busca de outras experiências. (Valls, 2000)

Outros aspectos importantes a serem analisados são a competitividade, atratividade e rentabilidade de cada um dos produtos e para isso, algumas metodologias de diagnósticos estratégicos, como a matriz de crescimento- 
participação de mercado da Boston Consulting Group e da matriz de atratividade de mercado-posição competitiva do destino desenvolvida pela General Eletric e pela consultoria McKinsey são instrumentos validos e aplicáveis'a realidadeturística (Bigné,Fonty Andreu,2000). Estas metodologias de análise também são conhecidas como "modelos de carteiras". "O uso de modelos de carteira ajudam a gestão do negócio, auxiliando os gestores a pensar de maneira mais estratégica auxiliando na compreensão econômica dos negócios". (Kotler, Bowen y Makens, 59:1997)

È extremamente importante compreender em que estágio de seu ciclo de vida os produtos turísticos de um destino se encontram e analisar os porquês de tal situação, sempre considerando que "o ciclo de vida dos destinos e produtos turísticos se desenvolve de maneira similar ao de todo produto de consumo" (Ejarque, 156:2003). O estudo do ciclo de vida dos produtos permite aos gestores públicos/privados tomarem decisões de forma estratégica de acordo com as característica de cada fase em que o produto se encontra. O estudo do "ciclo de vida de um produto não é um instrumento de "premonição" para determinar a duração da vida útil de um produto, mas sim, é um meio de conceituar o efeito do mercado, do ambiente e da competência, e compreender como este produto pode reagir a vários estímulos. Os produtos que não têm uma administração planejada viajam ao longo do ciclo de vida com pouca resistência" (Kotler, Bowen y Makens, 302:1997). "A principal utilidade do estudo do ciclo de vida dos destinos é que este nos permite compreender a evolução dos produtos turísticos e dos destinos e isso possibilita embasar a tomada de decisões estratégicas." (Buhalis, 97:2000)

Cada vez mais se deve assumir a importância do conceito de valor e, para isto, desde uma perspectiva de marketing, é necessário compreender a relação entre os conhecidos 4P's de McKarty e os 4C's de Louterboun, ambos muito 
trabalhados por Kotler em seus livros de marketing, ou seja, o composto do mix de marketing tradicional ou sob a ótica do produtor, que trabalha produto, preço, praça e promoção versus o conceito do mix de marketing sob a ótica do consumidor que trabalha o valor para o cliente, o custo para o cliente, a conveniência para o cliente e a comunicação dirigiada. Um comprador, ao avaliar um produto ou serviço, pode não vê-lo da mesma maneira que o vendedor. Os quatro P's podem ser mais bem descritos, do ponto de vista do comprador, como os quatro C's. Portanto, enquanto os profissionais de marketing se vêem como vendedores de um produto, os clientes se vêem como compradores de um valor ou da solução de um problema. E os clientes estão interessados em mais do que preço; estão interessados no custo total de obtenção, uso e descarte de um produto. Eles querem que o produto ou serviço esteja disponível da maneira mais conveniente possível. Por fim, os clientes não desejam promoção; querem uma comunicação bidirecional (Kotler, 2000). Ao evoluir esta discussão para o conceito de valor turístico, estudando-se as relações entre a oferta e a demanda no mercado turístico, se pode dizer que "o mercado turístico é o conjunto de relações de troca e de contatos entre os que querem vender e os que querem comprar mercadorias e estabelecer interações em um espaço determinado e contextualizado por uma sociedade com seus conjuntos de valores turísticos" (Lemos, 157:2005).

"É reconhecido o fato de que os destinos também são interpretados de maneira subjetiva pelos consumidores, dependendo da sua bagagem cultural, motivo de viagem, nível educacional e experiências passadas"(Buhalis, 116:200). Para alcançar a preferência dos turistas no momento da decisão de sua próxima viagem, os destinos precisam se reinventar e se estruturar enquanto produtos turísticos de maneira a exaltar os seus principais atributos e direcionar os seus esforços na busca do cliente ideal, ou seja, trabalhar os conceitos de superespecialização da oferta e supersegmentação da demanda. "A primeira coisa que um destino turístico em fase de renovação deve se preocupar é 
em definir determinados segmentos de mercado para captar e concentrarse em um número limitado deles, analisando cuidadosamente a que tipo de cliente se direcionará a oferta e em que tipos de produtos se desenham compatibilidades de acordo com o perfil do cliente almejado" (Ejarque, 89:2003).

O grande desafio de qualquer destino turístico é fazer com que o turista o eleja como o destino de sua próxima viagem, ante uma série de outras opções decorrente de uma grande concorrência existente neste mercado, que transcende fronteiras e distâncias em um mundo globalizado como o de hoje. Por isso o que se busca é mais do que um destino que ofereça produtos e serviços de qualidade, já que o que o turista busca são lugares que permitam um contato mais próximo com o local visitado, onde mais que visitar e contemplar, seja possível também viver, emocionar-se, ser personagem da sua própria viagem (Jensen, 1999). "Seguramente o êxito dos destinos turísticos em um futuro próximo dependerá muito da capacidade de aprender rapidamente e compreender bem todo o sistema psicológico do que se passa na cabeça dos turistas. Uma vez conhecido e entendido, devem se colocar em prática as estratégias aprendidas para conseguir alcançar melhores resultados." (Jaqueline Gil, 57:204)

O diagnóstico, como foi dito anteriormente, é "simplesmente" o início de um processo de planejamento, sem dúvida muito importante, porém, não se pode obviar que somente ter a coragem de reconhecer "como estamos" não basta. De nada adiantará todo o esforço realizado para a construção de um diagnóstico efetivamente acorde com a realidade, uma grande mobilização das autoridades, dos gestores e da comunidade local em geral, se posteriormente todos não partirem para uma nova fase, mudarem a sua forma de pensar geralmente passiva e reativa para uma atitude pró-ativa e voltada para uma maneira de pensar estratégica. Todos nós, de uma forma 
ou de outra, estamos acostumados e buscamos permanecer em nossa "zona de conforto", que nada mais é do que aquele ambiente a que estamos acostumados, a nossa rotina, às nossas atitudes mentais, enfim a tudo aquilo que nos é confortável, ou seja, aquilo que já estamos habituados. Todo processo de mudança vem precedido de expectativas e ansiedade. Mudar o status quo é uma tarefa árdua, que requer muita disciplina e perseverança. 


\section{METODOLOGIA}

A metodologia utilizada para a realização deste trabalho iniciou-se com a análise dos documentos produzidos para o município de Foz do Iguaçu. Havia uma quantidade considerável de Planos, Diagnósticos, Relatórios e Consultorias produzidas para o município em questão, mas também primouse em analisar trabalhos acadêmicos, projetos desenvolvidos por entidades de classes e até mesmo sugestões elaboradas por entidades de classe, pesquisas, dados estatísticos e material promocional.

Deve-se, no entanto, frisar que a divisão do conteúdo do material analisado baseou-se na metodologia proposta pela EMBRATUR 2007/2010 na qual há uma classificação por eixos temáticos que compreende: Planejamento e Gestão; Estruturação e Diversificação da Oferta; Fomento; Infra-estrutura; Promoção, Marketing e Apoio a Comercialização; Qualificação Profissional e Empresarial; Informação e Logística de Transporte.

Outra forma utilizada para verificar a veracidade das informações e até mesmo buscar outras que não estavam documentadas foi a realização de entrevistas pessoas qualitativas em profundidade com alguns atores sociais representativos do setor. Paralelamente à essas entrevistas também foi realizado um debate com atores sociais com o intuito de fazer uma análise situacional atual do município em questão.

Conforme dito anteriormente, para que pudesse dar veracidade à algumas propostas posteriormente sugeridas foi necessário buscar alguns dados secundários dando o embasamento necessário para o diagnóstico da atividade turística na região.

Baseado em todas as informações coletadas anteriormente, além de dados necessários na elaboração das propostas, foi realizado um seminário estratégico/participativo contando com a presença de importantes 
representantes do setor turístico em nível municipal, local e até mesmo estadual com o objetivo de validar e hierarquizar as propostas e sugestionar quais seriam os representantes responsáveis na execução de cada uma delas. 


\section{ANÁLISE/RESUMO DOCUMENTOS PRÉVIOS}

Baseado nos documentos analisados anteriormente foi possível identificar quais eram as requisições que havia uma incidência maior, ou seja, aquelas que se repetiam. Além disso, foi possível verificar que muitas das propostas encontradas nos primeiros planos e projetos também eram encontrados nos últimos, demonstrando que os responsáveis possuíam conhecimento do que precisava ser feito, a dificuldade estava na implementação dos mesmos.

Para uma análise, mas didática separou-se as propostas conforme os eixos temáticos definidos pela EMBRATUR 2007/2010. Para tal pode-se observar abaixo dentro de cada eixo, quais foram as principais requisições dos articuladores do turismo na região:

\section{Eixo Planejamento e Gestão}

Dentre as propostas analisadas observa-se que há uma maior "atenção" ao item que refere-se a melhorar a relação existente entre a iniciativa pública e privada, item este observado em praticamente todos os documentos analisados e corroborado após entrevistas pessoais. Os itens que referem-se à melhorar a legislação municipal relacinada do turismo e também melhorar a integração entre Brasil, Argentina e Paraguai tiveram um grande destaque.

\section{Eixo Estruturação e Diversificação da Oferta}

Há alguns projetos em desenvolvimento na região, principalmente ao que diz respeito à roteiros porém um dos pontos observados dentro deste eixo, nos documentos analisados, diz respeito a criação de projetos que trabalhem cultura e artesanato como produto turístico. Este item foi observado diversas vezes. Outros itens também citados com destaque dizem respeito à um trabalho com maior intensidade de roteiros integrados como o produto turístico "Pólo do Iguassu" e o roteiro integrado do Lago de Itaipu. 


\section{Eixo Fomento}

Este foi um tópico em que não foi encontrado um número de propostas tão grande quando nos demais eixos. Apesar de não haver uma quantidade grande de propostas algumas apareciam diversas vezes das quais destacamse os programas de incentivo fiscal, Estadual e Municipal, para a comunidade local. Outras formas de fomento destacadas diziam respeito à obtenção de recursos advindos do Parque Nacional do Iguaçu e também a obtenção de incentivos advindos da Itaipu Binacional.

\section{Eixo Infra-Estrutura}

No eixo que refere-se a Infra-Estrutura deve-se destacar que são contempladas tanto a infra-estrutura do município como a Infra-Estrutura Turística.Observouse que houve uma preocupação em inserir propostas que contemplassem os dois tipos de infra-estrutura, porém com uma ênfase maior à segurança urbana, sendo este o tópico com maior incidência. A preocupação no tocante à infra-estrutura turística estava baseada na melhoria da sinalização trilingüe assim como a duplicação e adequação da Av. das Cataratas e vias de acesso e finalmente a criação de postos de informação turística.

\section{Eixo Promoção, Marketing e Apoio Institucional}

Dentro deste eixo observou-se algumas particularidades, dentre elas a maior preocupação com a divulgação do município através de participação em feiras, congressos e eventos. Dentre as propostas com maior destaque a grande maioria esta focada em ações de captação de eventos; participação em eventos; apoio à Famtours e Fampress e a elaboração de um material promocional trilingue. 


\section{Eixo Qualificação}

Dentro deste eixo observou-se muitas propostas voltadas para a melhoria do serviçoa ser prestadoao turista envolvendo os indivíduos que possuem contato direto e até mesmo indireto com o turista. Propostas como a implementação e avaliação de programas de conscientização turística voltadas para a população corroboram com tal afirmação. Outra proposta que reforça esta preocupação é a que refere-se a criação de cursos de treinamento e aperfeiçoamento do Trade Turístico e todos os setores envolvidos diretamente. E finalmente outra proposta amplamente observada refere-se a criação de programas sócias para camadas marginalizadas como população de baixa renda ou até mesmo a população indígena.

\section{Eixo Informação}

De maneira semelhante ao que ocorreu com o eixo denominado "fomento"o eixo informação não possuiu um grande número de propostas dentro dos documentos analisados. Dentre os destaques ouve ênfase do SIIG que é o Sistema de Informação da Região Trinacional Iguassu que ainda não está estruturado. Outros pontos de destaque referem-se a informações e previsões sobre o fluxo de demanda e também o de dados relacionados a investimentos em turismo, de grandes cadeias hoteleiras e nichos em potencial.

\section{Eixo Logística De Transporte}

Este é um eixo bastante controverso pois muitos atribuiram a este os problemas hoje enfrentados pelo município de Foz do Iguaçu. O que ficou caracterizado dentro deste eixo é que o município sempre sofreu com problemas de vias de acesso. Esta afirmação pode ser corroborada com as propostas apresentadas nos planos que dizem que a melhoria do aeroporto; redução e equiparação 
das taxas aeroportuárias junto aos DAC e viabilização de vôos charters e com companhias aéreas são prioridades. Isto demonstra os problemas que o município sempre sofreu em relação ao transporte aéreo. Também houve destaque para a modernização de vias de acesso e rodoviária. 


\section{ANÁLISE SITUACIONAL}

A análise situacional, como o próprio nome já diz, faz um breve relato da situação de quatro fatores macro-ambientais sendo estes:

\section{Político}

Atualmente o Brasil encontrasse com um cenário conturbado com denuncias de escândalos e corrupção abalando a confiança internacional no país. Além disso, recentemente o Brasil perdeu uma posição no IDH (Índice de Desenvolvimento Humano) demonstrando que as ações tomadas pelo Governo Federal não foram suficientes para melhorar o país. O país pode ter melhorado, porém o restante do mundo melhorou em maior escala. Outro aspecto que deve ser levado em consideração é o ano eleitoral e o ano póseleitoral onde há incertezas em relação à Ministérios, equipe de governo, equipe econômica, entre outros. Um fator que não pode ser esquecido é a total desarticulação do Mercosul, praticamente inexistente na atualidade.

\section{Econômico}

Dentro do cenário econômico observam-se diversas incertezas como a economia internacional afetada pelo preço do petróleo, pela taxa de juros americana; pela pressão chinesa. Isso faz com que haja um crescimento econômico mundial, porém de forma desigual. Estes fatores influenciam diretamente na volatilidade do câmbio, impactando à turistas estrangeiros, além de impactar na inflação e taxa de juros. Dentro do cenário nacional devese frisar que o Brasil cresce, porém de forma muito aquém que as expectativas e de países emergentes como Rússia e Índia. Outro desafio que o Brasil deve ainda enfrentar refere-se a dívida interna e externa. 


\section{Social}

No âmbito social há alguns fatores a serem sanados sendo que o principal deles refere-se às desigualdades sociais existentes no Brasil. Aliado a este fator ainda há o não cumprimento das leis, o mercado de trabalho em constante alteração com uma parcela significativa da população com "trabalhos informais"e principalmente antigos e recentes problemas relacionados à segurança pública.

\section{Tecnológico}

O nível tecnológico aplicado no Brasil está crescendo porém em proporções menores que os índices encontrados na América Latina. A relação encontrada entre investimento em Pesquisa e Desenvolvimento e PIB é muito menor se compararmos com paises orientais ou até mesmo com a Rússia e/ou Chile. A sociedade atual é da informação e conhecimento o que faz com que muitos brasileiros não estejam inseridos na mesma. Uma ferramenta interessante é a Gestão da Informação que permite mapear o consumidor e verificar quais são suas características 
FOZ DO IGUACCU 01 - PÓLOS EMISSORES

\begin{tabular}{|c|c|c|c|c|c|c|c|c|}
\hline \multirow{2}{*}{$\begin{array}{l}\text { ESTADOS / } \\
\text { PAÍSES }\end{array}$} & \multicolumn{8}{|c|}{ ANOS (\%) } \\
\hline & 1995 & 1998 & 1999 & 2000 & 2001 & 2003 & $2004 \mathrm{e}$ & 2005 \\
\hline \multicolumn{9}{|l|}{ Estados } \\
\hline Parand & 20,6 & 21,0 & 30,2 & 27,5 & 31,9 & 31,5 & 28,5 & 28,6 \\
\hline Rio de Janeiro & 5,8 & 4,3 & 3,1 & 3,9 & 3,0 & 3,8 & 5,0 & 3,3 \\
\hline Rio Grande do Sul & 8,2 & 6,5 & 5,1 & 5,1 & 5,1 & 5,3 & 5,1 & 8,4 \\
\hline Santa Catarina & 5,6 & 5,2 & 6,6 & 4,5 & 5,1 & 4,8 & 4,1 & 8,7 \\
\hline São Paulo & 19,0 & 17,9 & 12,3 & 14,4 & 12,6 & 9,7 & 13,1 & 15,1 \\
\hline Outros Estados & 13,2 & 9,6 & 8,4 & 8,3 & 7,7 & 6,9 & 8,2 & 10,0 \\
\hline \multicolumn{9}{|l|}{ Paises } \\
\hline Alemanha & 2,9 & 2,1 & 3,8 & 2,8 & 1,9 & 1,5 & 1,8 & 0,9 \\
\hline Argentina & 10,5 & 17,4 & 9,6 & 12,4 & 13,3 & 15,2 & 14,9 & 5,8 \\
\hline Estados Unidos & 1,6 & 2,9 & 2,9 & 2,8 & 3,5 & 3,0 & 2,9 & 2,1 \\
\hline Paraguai & 0,6 & 0,8 & 1,2 & 1,0 & 1,0 & 4,1 & 2,4 & 4,4 \\
\hline Outros Paises & 12,0 & 12,3 & 16,8 & 17,3 & 14,9 & 14,2 & 14,0 & 12,7 \\
\hline TOTAL & 100,0 & 100,0 & 100,0 & 100,0 & 100,0 & 100,0 & 100,0 & 100,0 \\
\hline
\end{tabular}

Em gráfico acima observa-se que houve um aumento significativo da porcentagem de turistas oriundos de São Paulo. Também observa-se que os visitantes provenientes de Santa Catarina e Rio Grande do Sul aumentaram significativamente sua participação. Deve-se ater que o ano de 2004 é uma estimativa uma vez que não havia os dados, desta forma deve-se comparar o ano de 2003 com 2005. Já no cenário internacional houve uma queda muito grande de turistas provenientes da Argentina e Alemanha, em partes explicados pelo câmbio menos favorável 
FOZ DO IGUACUU 07 - MOTIVO DA VIAGEM

\begin{tabular}{l|r|r|r|r|r|r|r}
\hline \multirow{2}{*}{ MOTIVOS } & \multicolumn{7}{c}{ ANOS (\%) } \\
\cline { 2 - 9 } & 1995 & 1998 & 1999 & 2000 & 2001 & 2003 & 2005 \\
\hline Compras & 11,5 & 3,4 & 2,7 & 2,5 & 2,2 & 3,4 & 4,8 \\
Eventos & -- & 3,8 & 7,4 & 4,6 & 9,1 & 4,4 & 1,4 \\
Negócios & 21,3 & 15,3 & 22,5 & 23,9 & 32,3 & 20,3 & 15,7 \\
Parentes/Amigos & 14,4 & 15,5 & 13,8 & 15,1 & 11,1 & 11,9 & 20,3 \\
Lazer & 49,6 & 59,5 & 48,0 & 52,2 & 44,4 & 56,6 & 55,0 \\
Outros & 3,2 & 2,5 & 5,6 & 1,7 & 0,9 & 3,4 & 2,8 \\
\hline TOTAL & 100,0 & 100,0 & 100,0 & 100,0 & 100,0 & 100,0 & 100,0 \\
\hline
\end{tabular}

Em relação ao motivo da viagem o que chama atenção em especial é a queda que houve em pessoas viajando à Foz do Iguaçu para negócios e eventos, sendo que este último teve sua pior participação desde 1998. Em compensação pessoas visitando parentes e/ou amigos cresceu, quase que dobrando o percentual. Deve-se ressaltar que este tipo de turista gasta menos que turistas que vão a negócios ou eventos. 
FOZ DO IGUAÇU 12 - DEFINIÇÃO DA IMAGEM DA CIDADE

\begin{tabular}{l|r|r|r}
\hline \multirow{2}{*}{\multicolumn{1}{c}{ IMAGEM }} & \multicolumn{3}{c}{ INDICE (\%) } \\
\cline { 2 - 5 } & 2001 & \multicolumn{1}{c}{2003} & \multicolumn{1}{c}{2005} \\
\hline Cidade Ecológica & 43,8 & 17,9 & 20,3 \\
Cidade com Qualidade de Vida & 13,1 & 2,5 & 4,6 \\
Cidade Cultural & 5,9 & 1,8 & 1,6 \\
Cidade Turistica & 22,6 & 71,8 & 68,7 \\
Outras & 14,6 & 6,0 & 4,8 \\
\hline TOTAL & 100,0 & 100,0 & 100,0 \\
\hline
\end{tabular}

Fonte: Paraná Turismo

Em relação a imagem que há do município houve uma inversão de percepção por parte do turista onde anteriormente ele via Foz do Iguaçu como uma cidade ecológica e hoje há uma concepção muito mais forte de cidade turística. 
No gráfico baixo pode-se perceber que os três principais atrativos Parque Nacional do Iguaçu (Brasil), Parque Nacional do Iguazzu (Argentina) e Itaipu Binacional correspondem a 77\% do total dos atrativos visitados demonstrando a concentração dos visitantes em apenas três atrativos enquanto que o município tem uma porção muito maior para oferecer.

\title{
PRINCIPAIS ATRATIVOS TURÍSTI COS font e: SERRAE COMTUR. UFSC
}

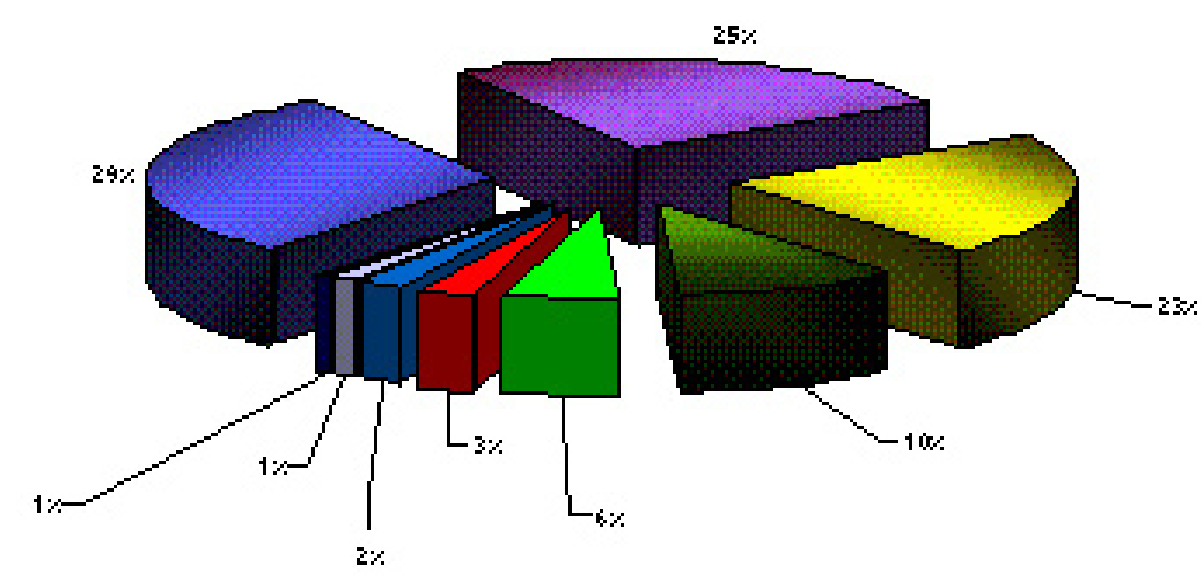

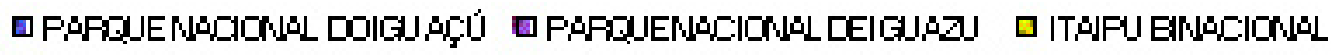 \\ I MACJCOSAFAFI

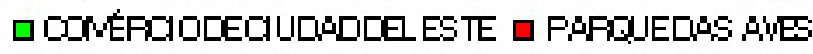 \\ 口 SHOWSNOTUFNDS \\ 口CASSINAS \\ - CONERZIOCEFUERTOIGJAZJ
}




\title{
FLUXO DE HÓSPEDES FOZ DO IGUAÇÚ
}

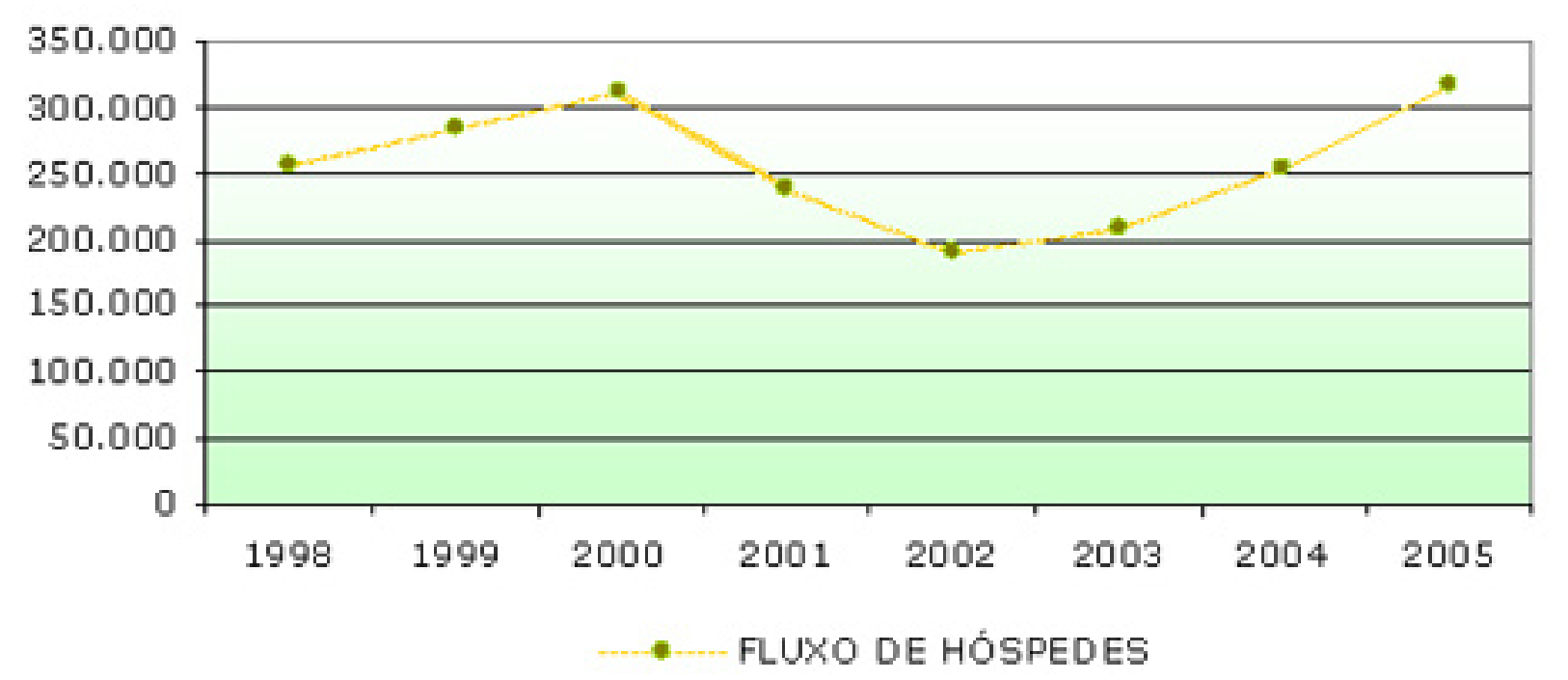

Fonte: Paraná Turismo

\begin{abstract}
No gráfico acima observa-se o fluxo de hóspedes em Foz do Iguaçu corroborando com a informação que não há uma crise no setor. Se houve uma crise ela deve ter ocorrido no ano de 2002 onde pode-se observar o menos fluxo de turistas desde 1998. Ainda observa-se que o ano de 2000 possui um fluxo de turistas muito semelhante ao ano de 2005.
\end{abstract}


Número de Passageinos

fonte INF RAERO

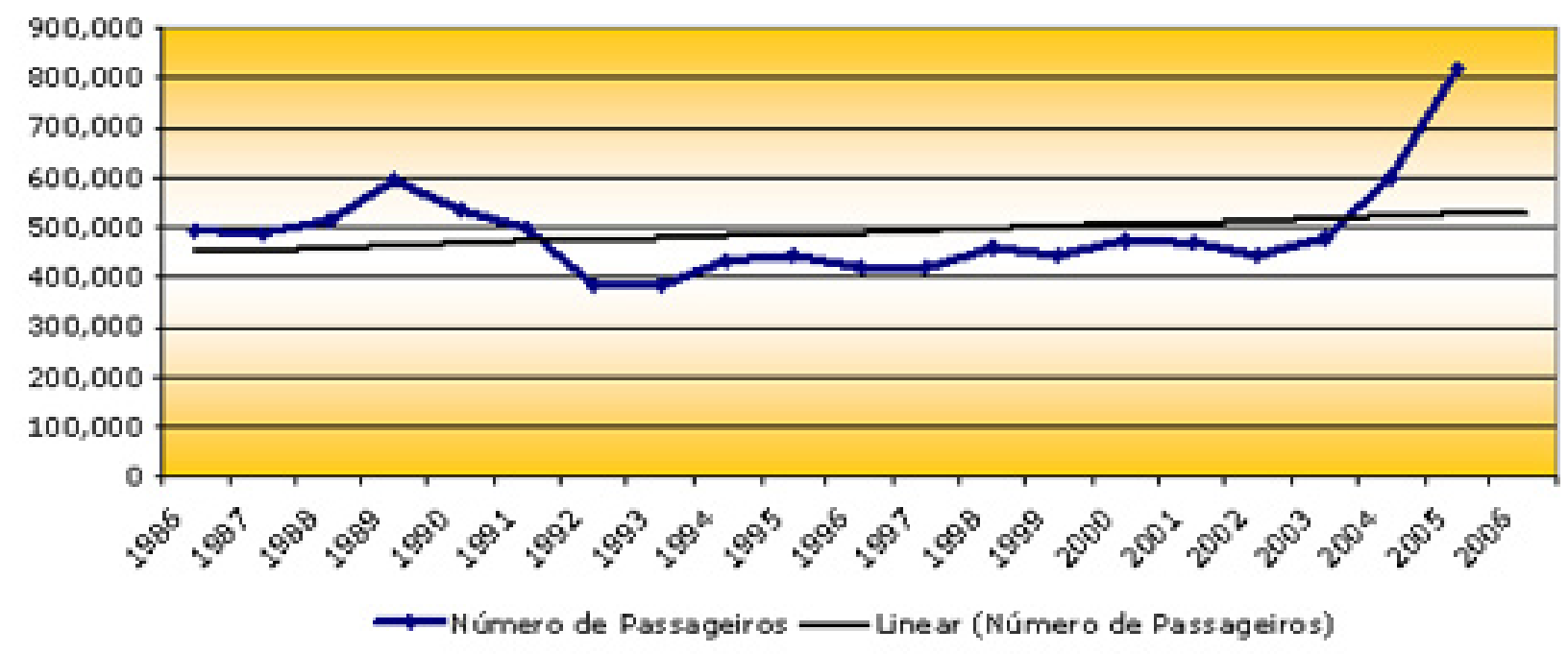

Fonte: Paraná Turismo

Outro dado interessante a ser observado diz respeito ao crescimento do número de passageiros utilizando o modal aéreo. Apesar das dificuldades sempre enfrentadas pelo município percebe-se um crescimento considerável no número de passageiros utilizando este modal. Este crescimento fica muito claro a partir do ano de 2003. 


\section{Comparativos de Ocupacao Hoteleira}

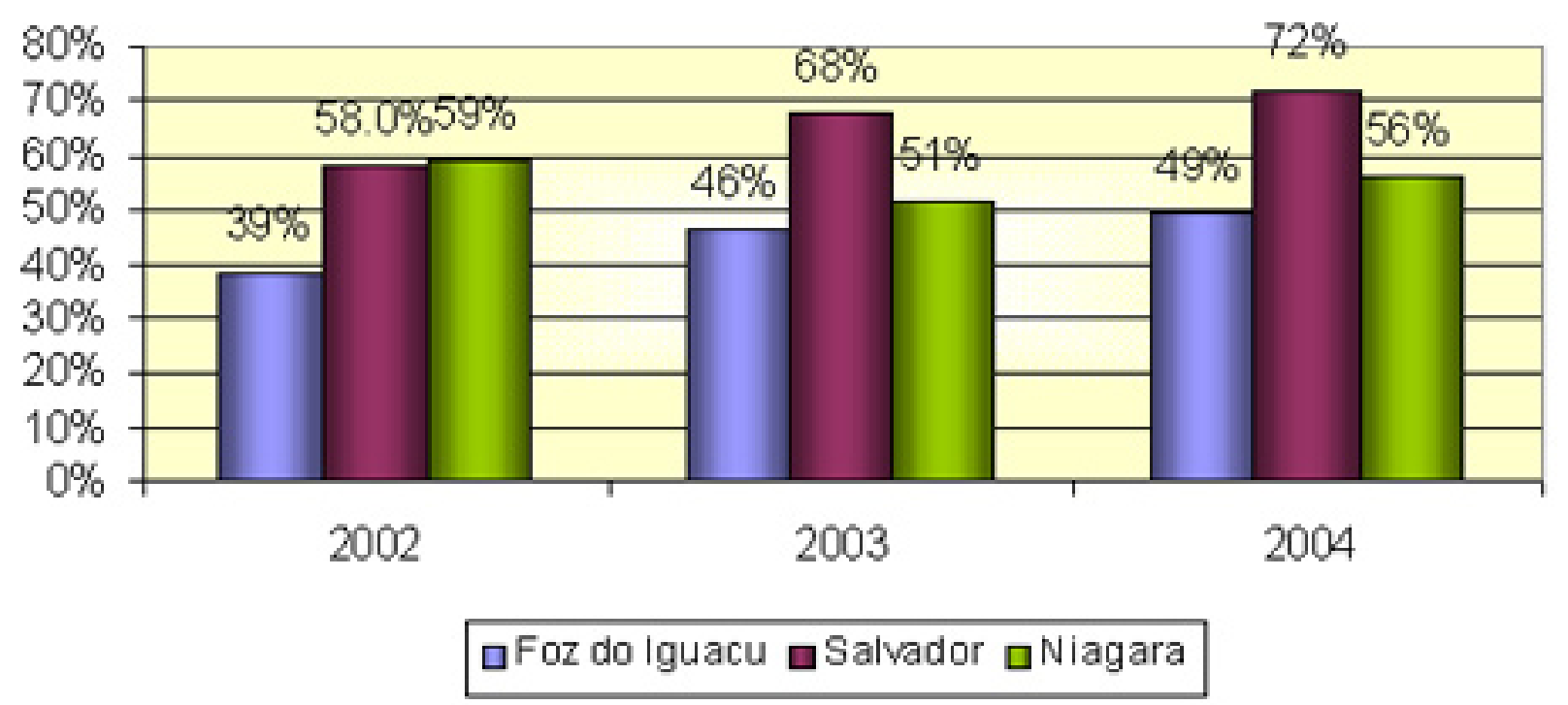

Fonte: Paraná Turismo

Fazendo uma comparação com a média de ocupação hoteleira de outros dois destinos que podem ser considerados concorrentes, observa-se que a ocupação deFoz dolguaçuéa menor delas demonstrando uma potencialidade de crescimento, principalmente se estiver querendo comparar-se à Niagara Falls. 


\section{DIAGNÓSTICO}

Para a realização do diagnóstico foi utilizada a metodologia de analise SWOT (Forças, Fraquezas. Oportunidade e Ameaças). Por uma questão didática dividiu-se por eixo temático para ficar mais fácil a visualização do que ocorre em cada um deles e suas características independentemente. Ao fazer uma análise SWOT do município como um todo cria-se uma dependência muito grande de um item ao outro e desta maneira é muito mais fácil observar o que ocorre em cada um deles.

\section{Planejamento e Gestão}

\begin{tabular}{|c|c|}
\hline Pontos Fortes & Pontos Fracos \\
\hline $\begin{array}{l}\text { - Existência de diversas estruturas/ } \\
\text { organizações relacionadas ao turismo; }\end{array}$ & $\begin{array}{l}\text { - Desarticulação das diversas } \\
\text { estruturas existentes; }\end{array}$ \\
\hline $\begin{array}{l}\text { - A iniciativa pública reconhece } \\
\text { a importância do turismo para a } \\
\text { economia local; }\end{array}$ & $\begin{array}{l}\text { - Apesar de reconhecerem a } \\
\text { necessidade a relação iniciativa } \\
\text { público/privada ainda é deficitária; }\end{array}$ \\
\hline $\begin{array}{l}\text { • Compreensão da importância de um } \\
\text { trabalho conjunto como “Destino” } \\
\text { com as cidades próximas; Criação } \\
\text { do COMTUR para acompanhar e } \\
\text { coordenar a implementação das } \\
\text { ações/relações da iniciativa público- } \\
\text { privada. }\end{array}$ & $\begin{array}{l}\text { - As relações entre os países vizinhos } \\
\text { (Argentina e Paraguai) é complexa; } \\
\text { • Apesar de ser a principal atividade } \\
\text { econômica da região o setor ainda } \\
\text { tem pouca representatividade } \\
\text { política; Orçamento da Secr. de } \\
\text { Turismo não compatível com a } \\
\text { importância da atividade para a } \\
\text { economia local. }\end{array}$ \\
\hline
\end{tabular}




\begin{tabular}{|c|c|}
\hline Oportunidades & Ameaças \\
\hline $\begin{array}{l}\text { - Articulação das diversas estruturas } \\
\text { existentes; }\end{array}$ & $\begin{array}{l}\text { • Não entendimento entre os agentes } \\
\text { envolvidos; }\end{array}$ \\
\hline $\begin{array}{l}\text { - Articulação público/privada; } \\
\text {-Aprimorar o processo de } \\
\text { desenvolvimento do turismo } \\
\text { na região através de políticas } \\
\text { estruturadas junto as cidades vizinhas; }\end{array}$ & $\begin{array}{l}\text { - Trabalhos "paralelos", ou seja, uma } \\
\text { instituição realizando o mesmo tipo } \\
\text { de trabalho que outra; }\end{array}$ \\
\hline $\begin{array}{l}\text { - Desenvolver o turismo na região de } \\
\text { fronteira (Argentina, Paraguai e Brasil) } \\
\text { por intermédio de negociações com } \\
\text { tais países; Desenvolver uma unidade } \\
\text { que fortaleça a relação entre iniciativa } \\
\text { pública/privada e associações } \\
\text { relacionadas ao turismo. }\end{array}$ & $\begin{array}{l}\text { • Competição pelo "poder", } \\
\text { conseqüentemente um } \\
\text { enfraquecimento do conjunto; } \\
\text { • Trabalhos isolados de cada um dos } \\
\text { países; } \\
\text { - Queda no fluxo de turista devido a } \\
\text { falta de um planejamento adequado } \\
\text { para a atividade. }\end{array}$ \\
\hline
\end{tabular}




\section{Estruturação e Diversificação da Oferta}

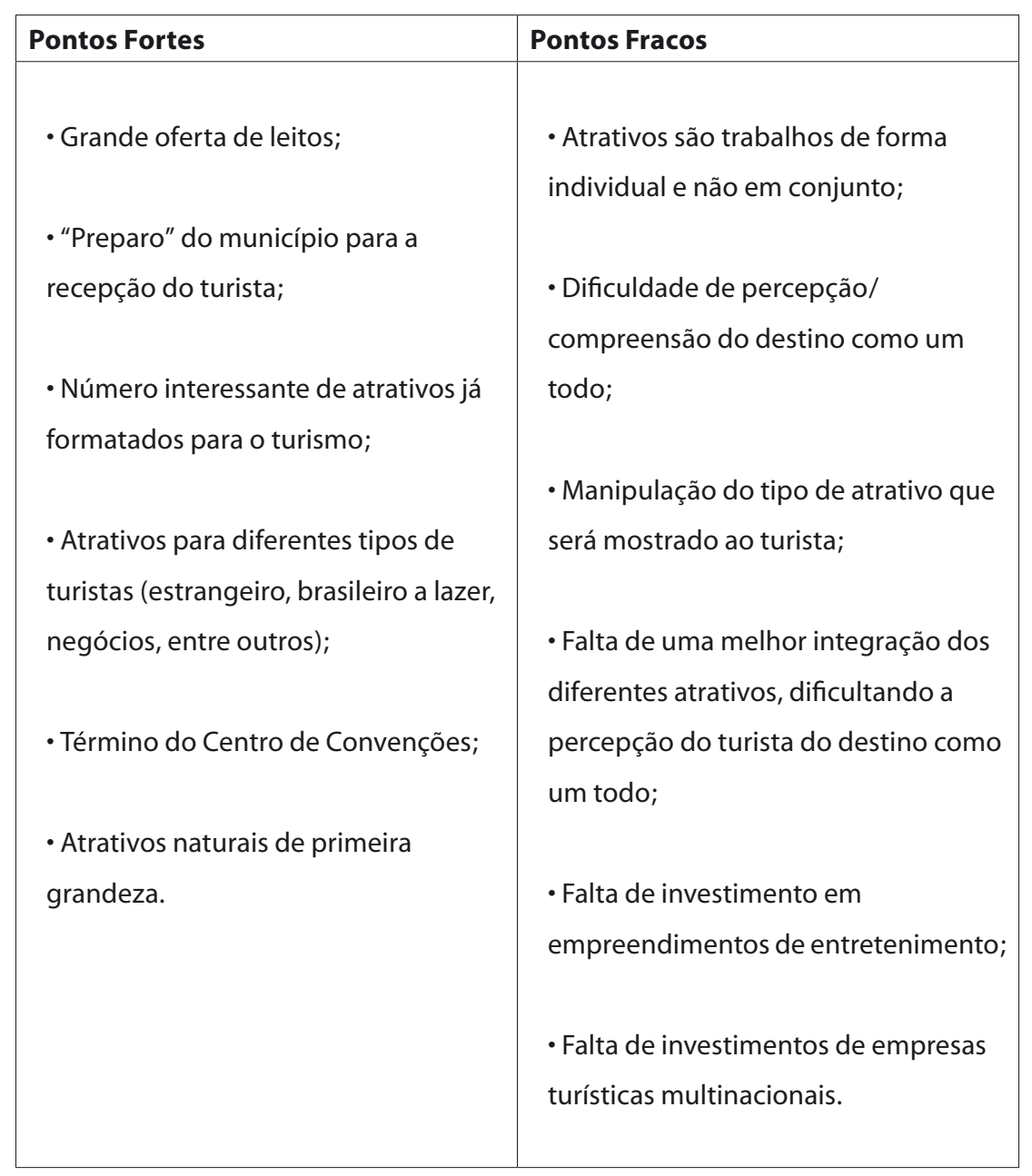




\begin{tabular}{|c|c|}
\hline Oportunidades & Ameaças \\
\hline $\begin{array}{l}\text { - Potencial de atração de um número } \\
\text { maior de turistas; }\end{array}$ & $\begin{array}{l}\text { - Falta de investimentos na oferta já } \\
\text { existente; }\end{array}$ \\
\hline $\begin{array}{l}\text { - Divulgação de novos produtos } \\
\text { fazendo com que pessoas que já } \\
\text { conheçam Foz possam retornar; }\end{array}$ & $\begin{array}{l}\text { - Falta de caracterização da cultura e } \\
\text { artesanato local; }\end{array}$ \\
\hline $\begin{array}{l}\text { • Estruturação de roteiros turísticos } \\
\text { regionais; }\end{array}$ & $\begin{array}{l}\text { - Possibilidade de concorrência com } \\
\text { países próximos; }\end{array}$ \\
\hline $\begin{array}{l}\text { - Possibilidade de trabalhar os mais } \\
\text { diversos tipos de turistas em uma } \\
\text { região; }\end{array}$ & $\begin{array}{l}\text { - Aumento da oferta hoteleira na } \\
\text { Argentina em um curso espaço de } \\
\text { tempo; }\end{array}$ \\
\hline $\begin{array}{l}\text { - Melhor definição do produto Pólo do } \\
\text { Iguassu e Roteiros Integrados do Lago } \\
\text { de Itaipu; }\end{array}$ & $\begin{array}{l}\text { - Consolidar a imagem do destino } \\
\text { de cidade de baixa permanência } \\
\text { devido a falta de integração dos } \\
\text { atrativos e/ou pela falta de atrativos } \\
\text { complementares. }\end{array}$ \\
\hline $\begin{array}{l}\text { - Possibilidade de criação de uma } \\
\text { historia e cultura local. }\end{array}$ & \\
\hline $\begin{array}{l}\text { - Melhor utilizar a estrutura existente } \\
\text { no Lago de Itaipu e Usina de Itaipu }\end{array}$ & \\
\hline
\end{tabular}




\section{Fomento}

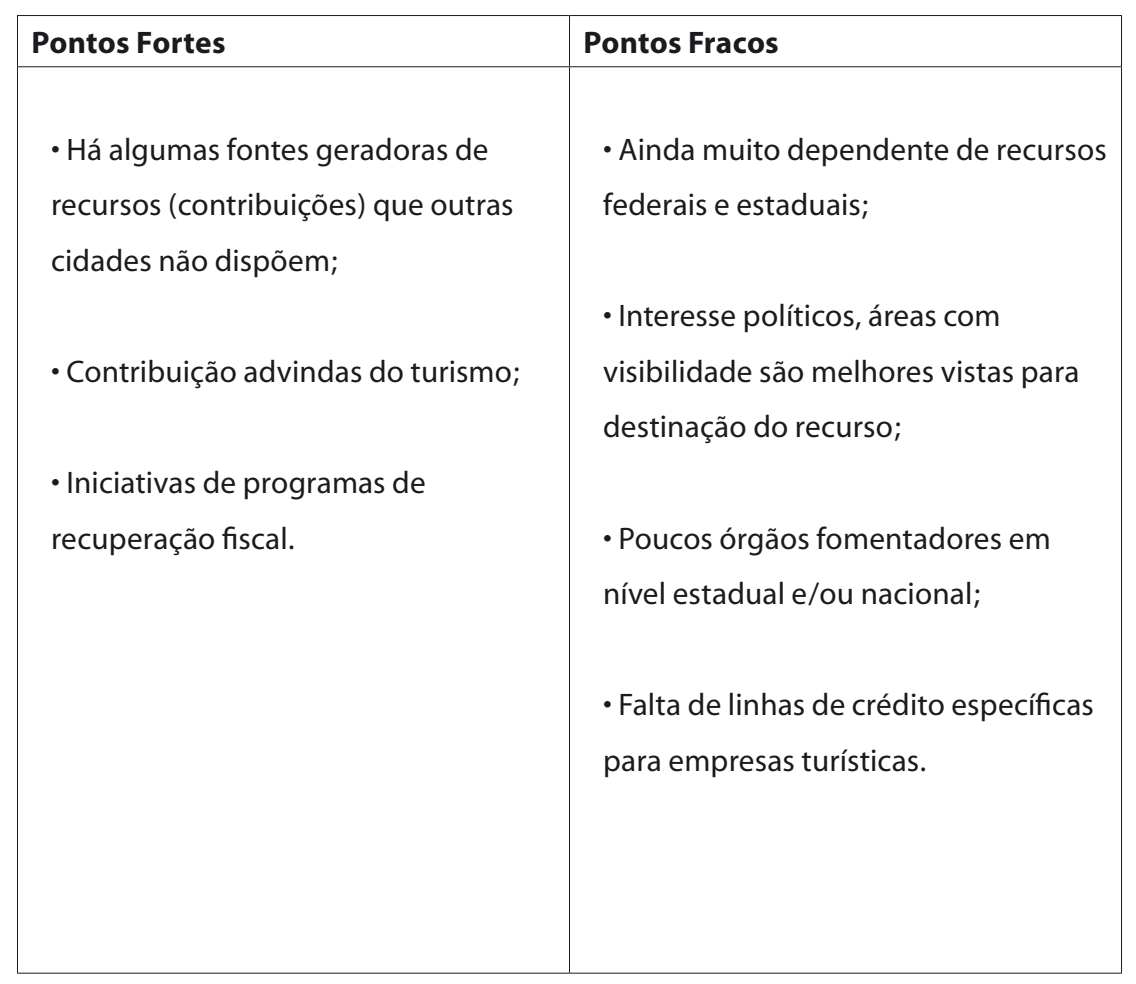




\begin{tabular}{|c|c|}
\hline Oportunidades & Ameaças \\
\hline $\begin{array}{l}\text { - Criação de um fundo de } \\
\text { investimentos/promoção proveniente } \\
\text { das receitas oriundas da utilização de } \\
\text { atrativos e equipamentos turísticos; } \\
\text { • Incentivo fiscais; } \\
\text { •Incentivo a vinda de novos } \\
\text { empreendedores, para que possam } \\
\text { complementar a oferta e gerir mais } \\
\text { recursos; } \\
\text { • Incentivos fiscais da prefeitura para } \\
\text { atrair investidores internacionais; } \\
\text { • Itaipu e Parque Nacional do Iguaçu } \\
\text { podem se tornar fonte de fomento. } \\
\text { • Promoção dos resultados da } \\
\text { atividade no município visando } \\
\text { despertar o interesse das empresas } \\
\text { turísticas multinacionais. }\end{array}$ & $\begin{array}{l}\text { • Órgãos de fomentos em países } \\
\text { vizinhos mais eficientes; } \\
\text { • Redução da arrecadação em função } \\
\text { de benefícios fiscais; } \\
\text { • Pouca atratividade da região para a } \\
\text { captação de indústrias; } \\
\text { • Estagnação do empresariado } \\
\text { e consequentemente dos fluxos } \\
\text { turísticos. . }\end{array}$ \\
\hline
\end{tabular}




\section{Infra-Estrutura}

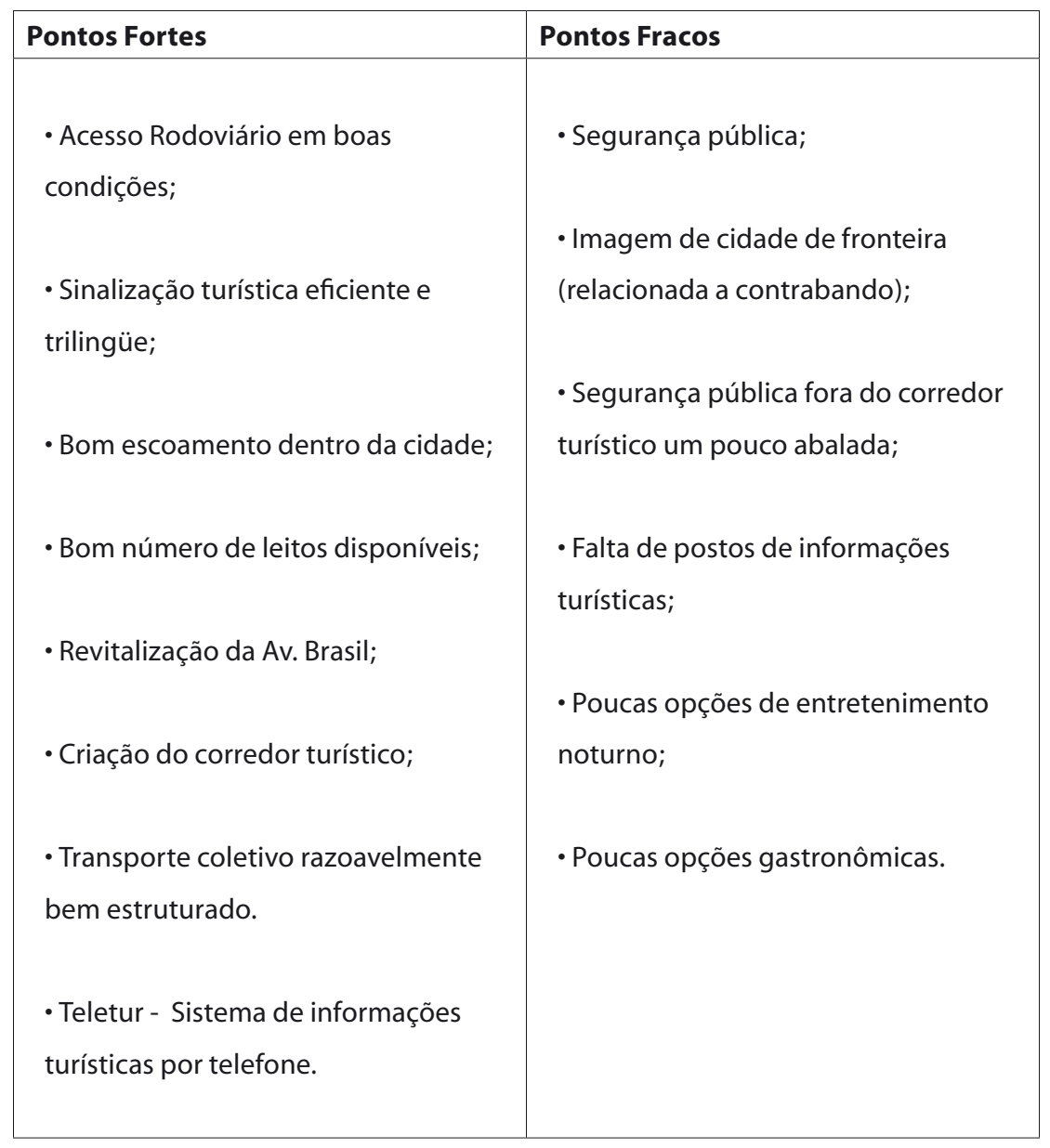




\begin{tabular}{|c|c|}
\hline Oportunidades & Ameaças \\
\hline $\begin{array}{l}\text { - Criar um modelo de transporte } \\
\text { exclusivamente turístico. } \\
\text { • Criação de um posto de informação } \\
\text { ao turista }\end{array}$ & $\begin{array}{l}\text { - Aumento da criminalidade } \\
\text { - Aumento da taxa de desemprego } \\
\text { - Aumento da tensão social com a } \\
\text { abertura da nova aduana da Recieta } \\
\text { Federal }\end{array}$ \\
\hline
\end{tabular}




\section{Promoção, Marketing e Comercialização}

\begin{tabular}{|c|c|}
\hline Pontos Fortes & Pontos Fracos \\
\hline $\begin{array}{l}\text { • Atualmente Foz do Iguaçu já e } \\
\text { reconhecida nacionalmente e } \\
\text { internacionalmente; } \\
\text { - Participação em Feiras e Eventos } \\
\text { como um dos principais produtos do } \\
\text { Brasil; } \\
\text { - Iniciativa privada alavancando a } \\
\text { captação de eventos para a cidade, } \\
\text { independentemente de apoio de } \\
\text { terceiros; } \\
\text { • Investimentos em Famtour's e } \\
\text { Fampress's.. }\end{array}$ & $\begin{array}{l}\text { - Trabalho individualizado de } \\
\text { comercialização; } \\
\text { • Imagem sem características muito } \\
\text { definidas; } \\
\text { - Stand que não expressa o potencial } \\
\text { do destino; } \\
\text { - Falta de um plano de marketing } \\
\text { estratégico que defina os segmentos } \\
\text { desejados e estabeleça as políticas } \\
\text { de produto, preço, distribuição e } \\
\text { comunicação; } \\
\text { • Falta de uma política de } \\
\text { comunicação integrada entre o poder } \\
\text { público, ICVB e iniciativa privada. } \\
\text { posicionamento adequada e } \\
\text { difundida entre as empresas turísticas } \\
\text { e turistas; }\end{array}$ \\
\hline
\end{tabular}




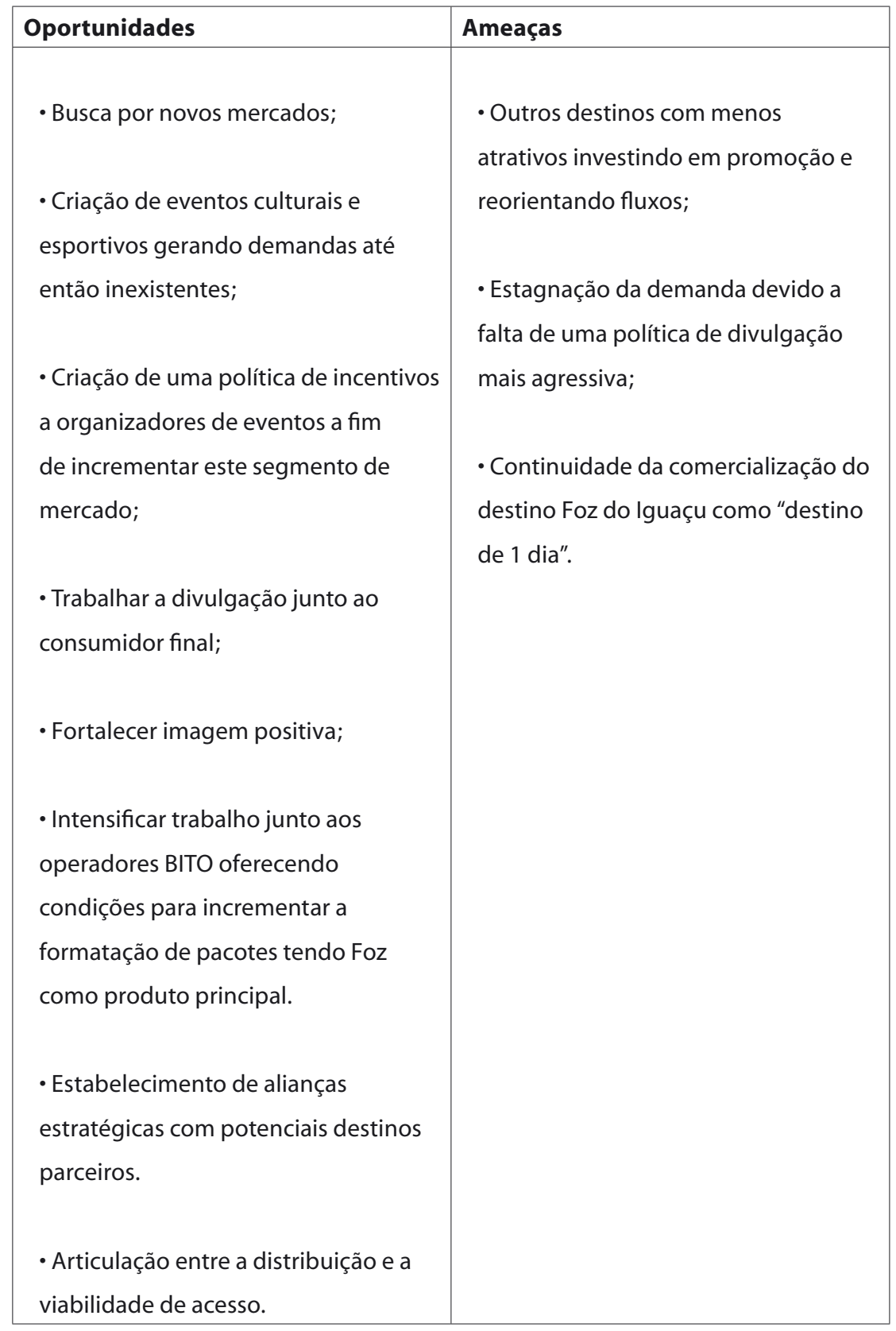




\section{Qualificação}

\begin{tabular}{|c|c|}
\hline Pontos Fortes & Pontos Fracos \\
\hline $\begin{array}{l}\text { - Projetos de educação para o turismo } \\
\text { no ensino fundamental; }\end{array}$ & $\begin{array}{l}\text { - Baixa qualificação de alguns setores } \\
\text { envolvidos com o Trade Turístico; }\end{array}$ \\
\hline $\begin{array}{l}\text { • Ampla discussão em torno de } \\
\text { programas de conscientização } \\
\text { turística; }\end{array}$ & $\begin{array}{l}\text { - Falta de investimento do Trade na } \\
\text { mão-de-obra que possui contato com } \\
\text { o turista. }\end{array}$ \\
\hline $\begin{array}{l}\text { - Projeto em fase de implementação } \\
\text { de qualificação de mão-de-obra para } \\
\text { o turismo com foco em vendas e } \\
\text { marketing. }\end{array}$ & \\
\hline Oportunidades & Ameaças \\
\hline $\begin{array}{l}\text { • Motivação de Gestores Públicos e } \\
\text { Privados; } \\
\text { •Iniciar um processo de "Gestão de } \\
\text { Mudanças" }\end{array}$ & • Não desenvolver ações necessárias. \\
\hline
\end{tabular}




\section{Informação}

\begin{tabular}{|c|c|}
\hline Pontos Fortes & Pontos Fracos \\
\hline $\begin{array}{l}\text { - Projeto para criação de um Sistema } \\
\text { de Informação para a região } \\
\text { Trinacional. }\end{array}$ & $\begin{array}{l}\text { - Falta de um estudo detalhado do } \\
\text { comportamento de compra do turista } \\
\text { que visita Foz do Iguaçu; } \\
\text { - As entidades envolvidas com o } \\
\text { turismo não conhecem o turista que } \\
\text { visita Foz do Iguaçu. } \\
\text { - Desconhecer o tipo de turista que } \\
\text { freqüenta o município; } \\
\text { - Desconhecer os reais impactos, } \\
\text { positivos e negativos, econômicos, } \\
\text { sociais e ambientais, que a atividade } \\
\text { turística ocasiona na região. }\end{array}$ \\
\hline
\end{tabular}




\begin{tabular}{|l|l|}
\hline Oportunidades & Ameaças \\
\hline • Criação de um centro de pesquisas, & • Não conhecendo o turista que possui \\
com o apoio das universidades. & Foz do Iguaçu poderá direcionar \\
& suas estratégias de Marketing para o \\
• Criação de um observatório de & público errado \\
turismo para conhecer características & \\
dos visitantes da região. & \\
• Conhecer o perfil dos turistas para & \\
direcionar ações de captação. & \\
\end{tabular}




\section{Logística de Transporte}

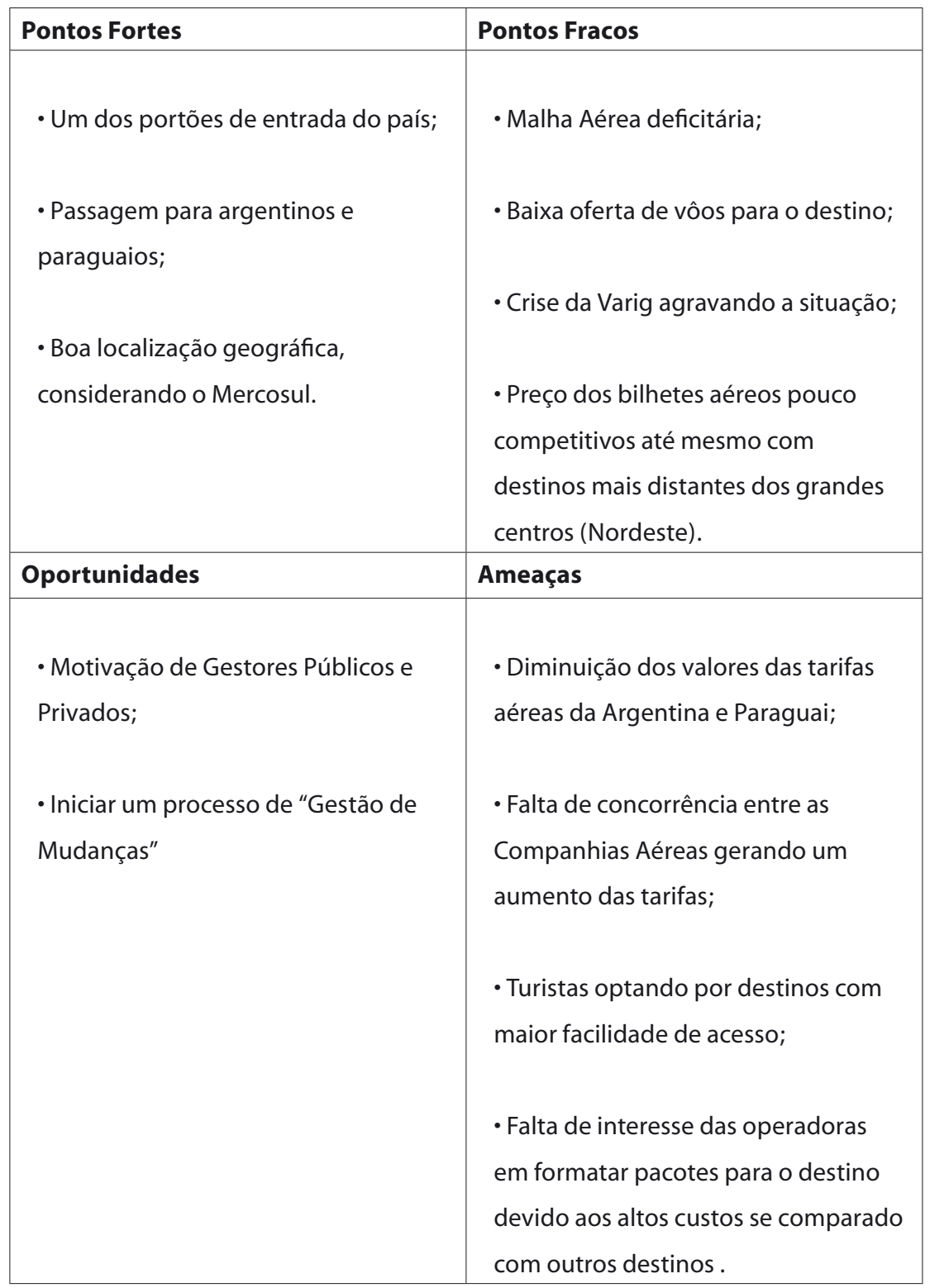


Dentro do diagnóstico ainda fez se referencia aos principais produtos turísticos a serem considerados na região e assim como seu "produto periférico". Desta forma definiu-se como três os produtos principias e seus respectivos periféricos conforme pode ser observado abaixo:

\section{Turismo de Ambiente de Fronteira}

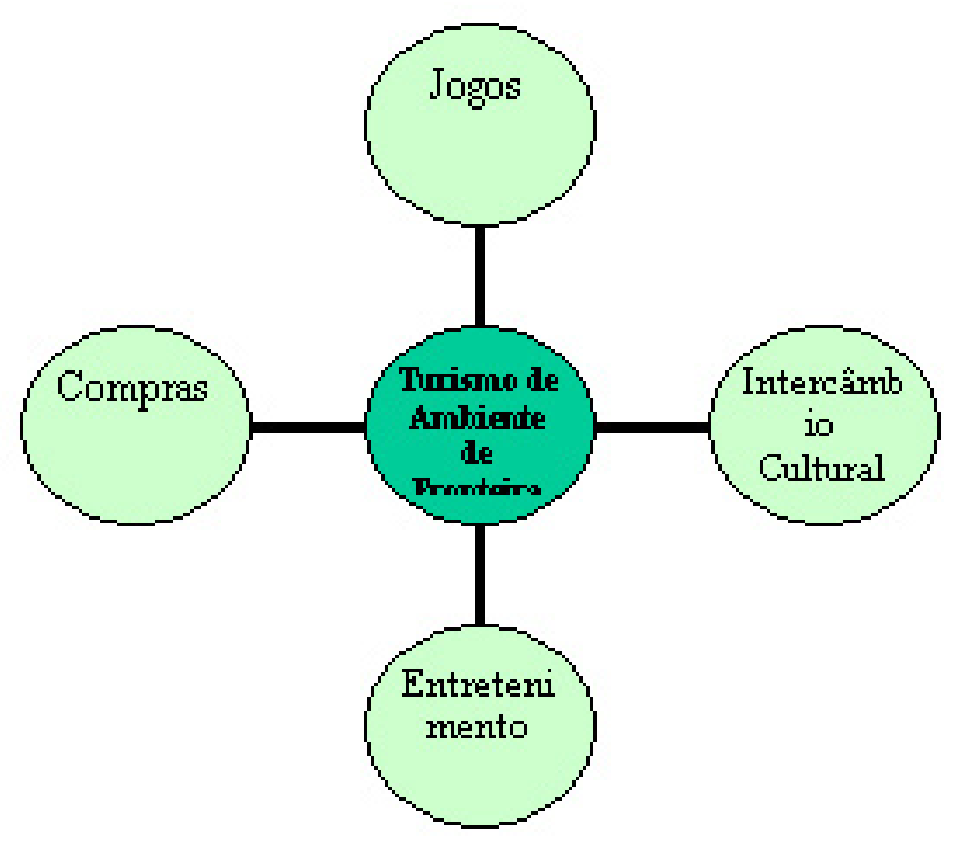

Fonte: Adaptado de Buhalis e Fletcher (1995) 


\section{Turismo de Eventos}

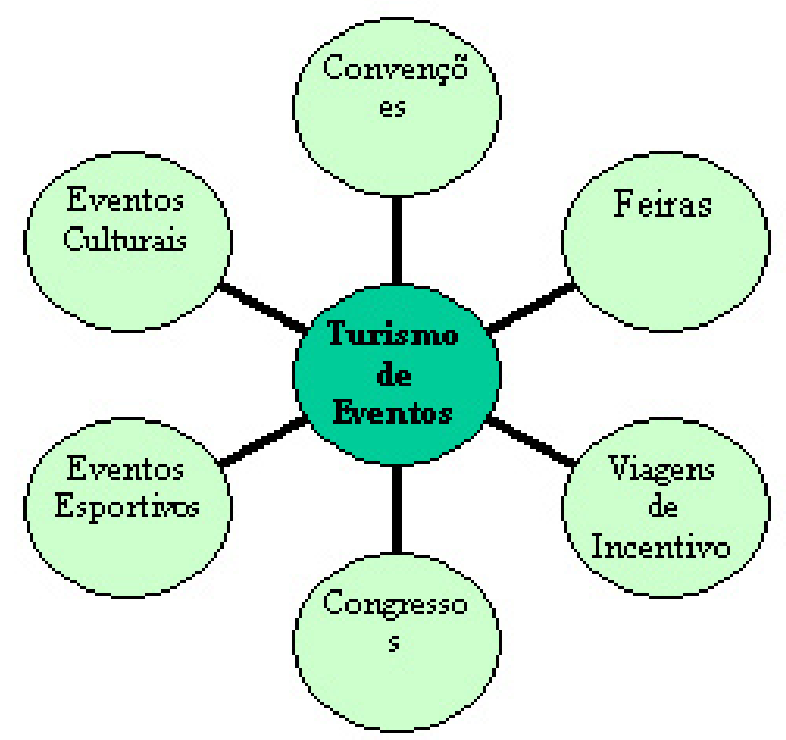

Fonte: Adaptado de Buhalis e Fletcher (1995)

\section{Turismo de Natureza}

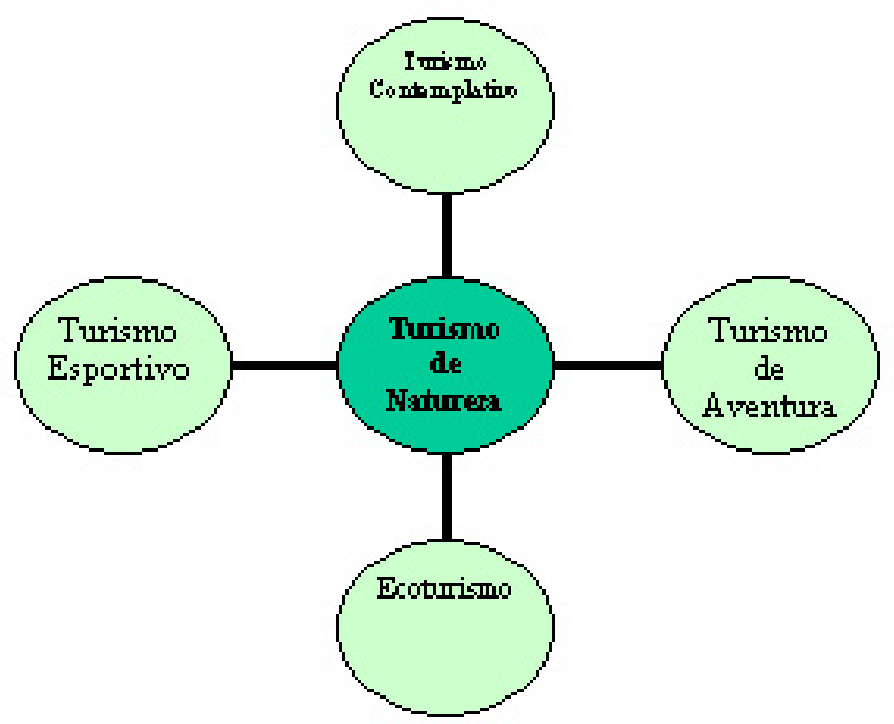

Fonte: Adaptado de Buhalis e Fletcher (1995) 
DIAGNÓSTICO ESTRATÉGICO

\section{Matriz BCG}

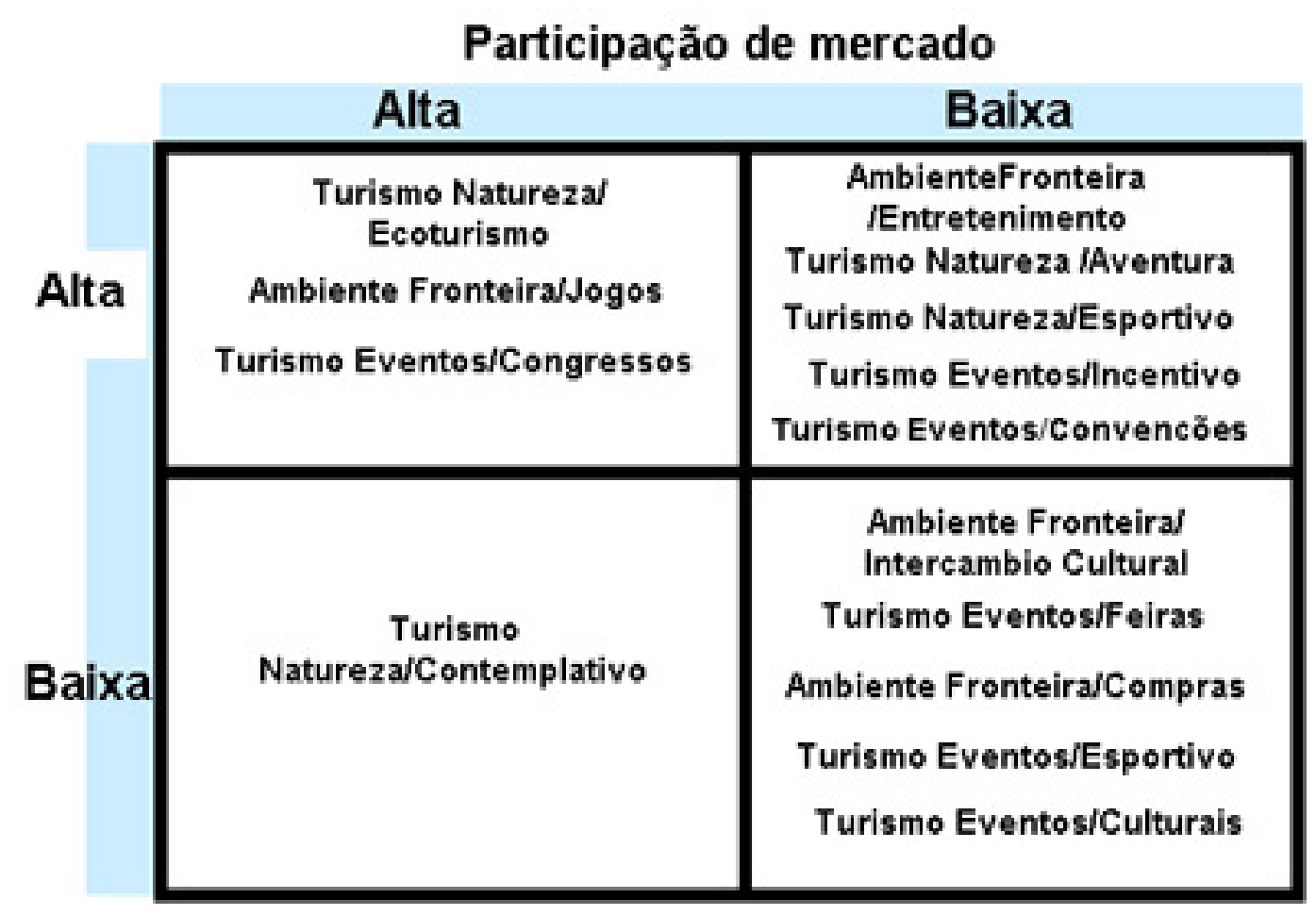

Fonte: Adaptado de Kotler, Bowery Makens (1997) 


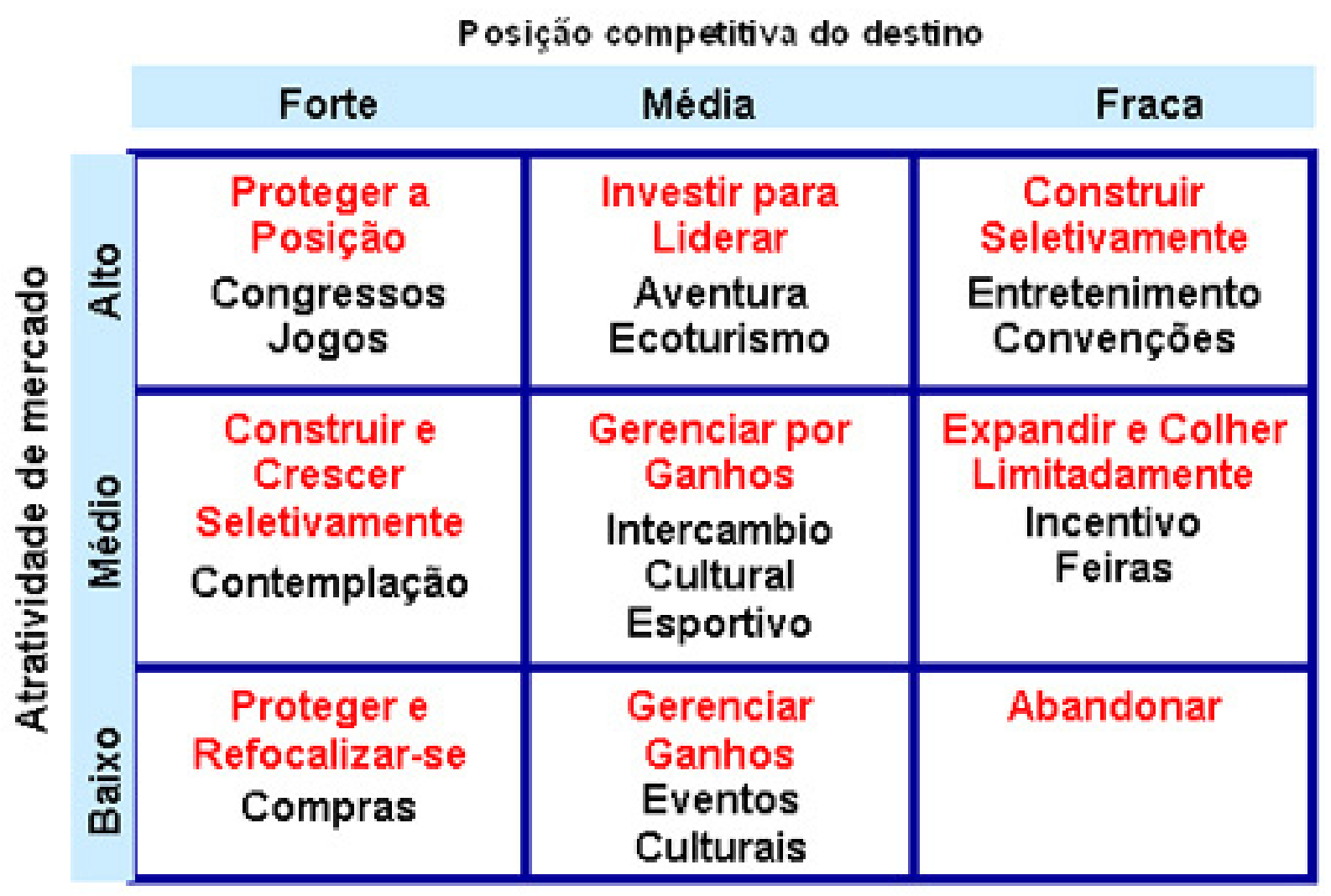




\section{Ciclo de Vida}

É a caracterização de em que estágio o produto se encontra. Todo produto tem um período de crescimento e maturidade e posteriormente entra na saturação, neste momento é necessária uma atenção especial para verificar a continuidade, ou não, do mesmo.

\section{CICLO DE VIDA DE UM PRODUTO TURISMO DE NATUREZA}

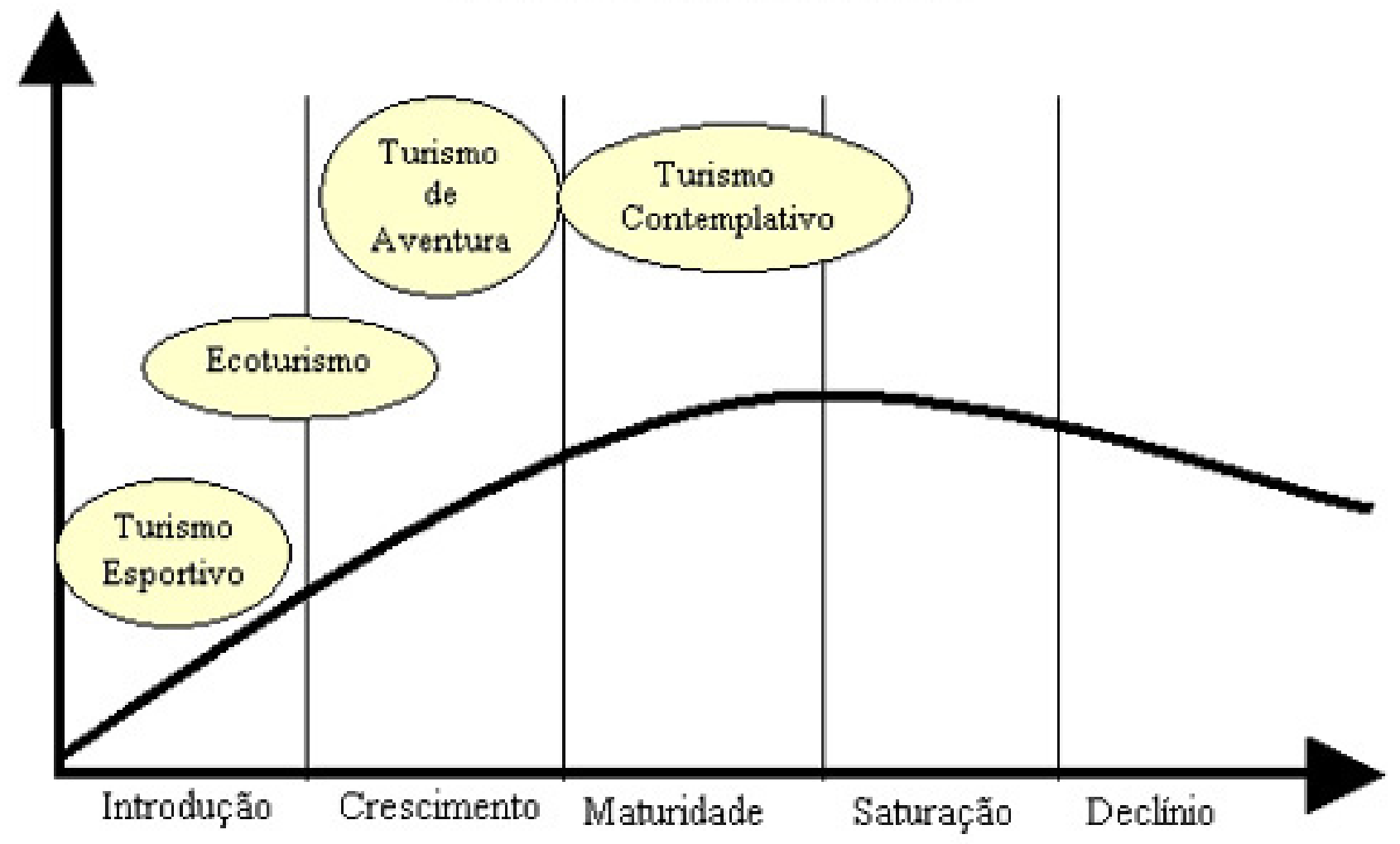




\section{CICLO DE VIDA DE UM PRODUTO TURISMO DE EVENTOS}

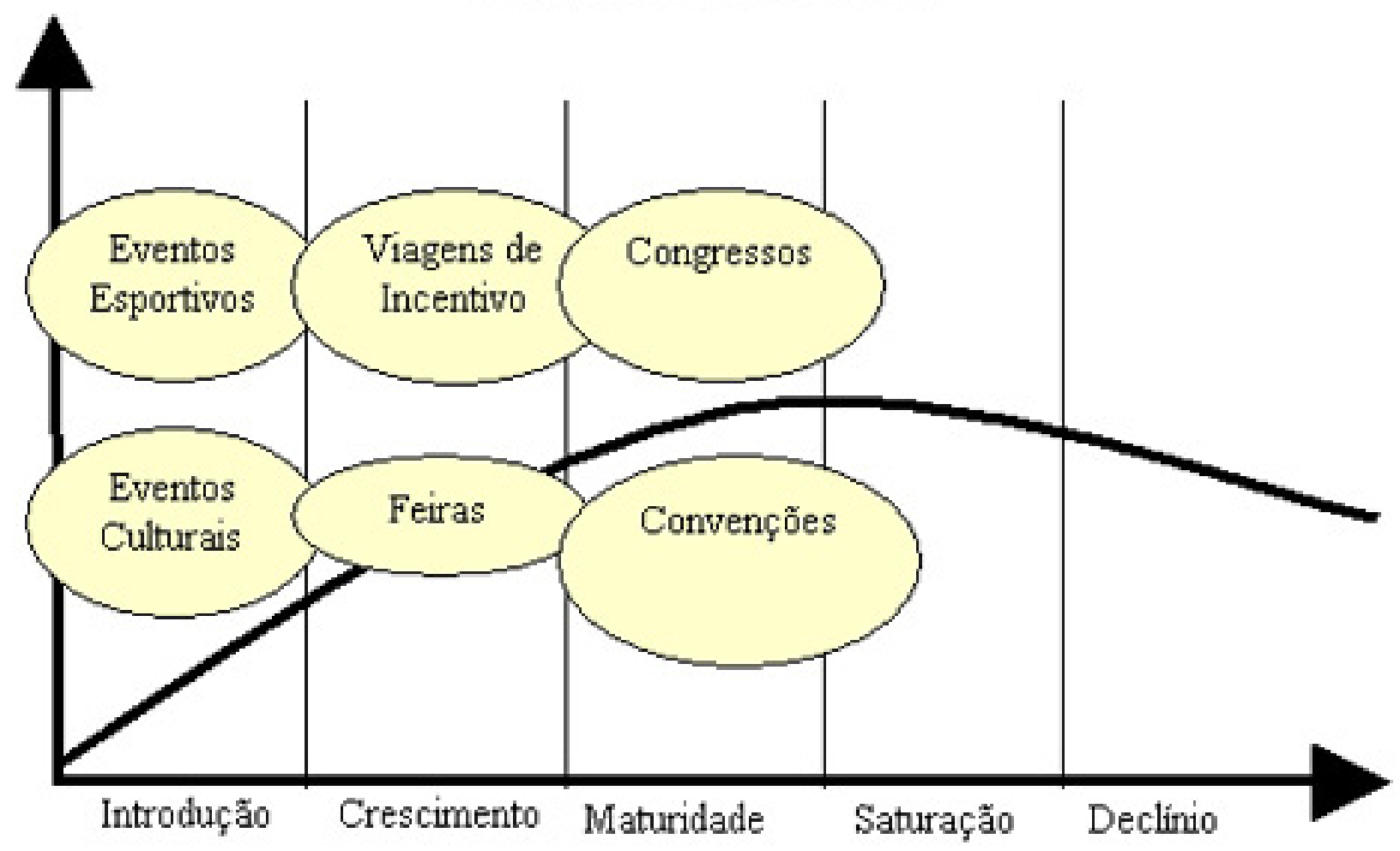

Fonte: Adaptado de D. Buhalis (2000) 
CICLO DE VIDA DE UM PRODUTO

TURISMO DE AMBIENTE DE FORNTEIRA

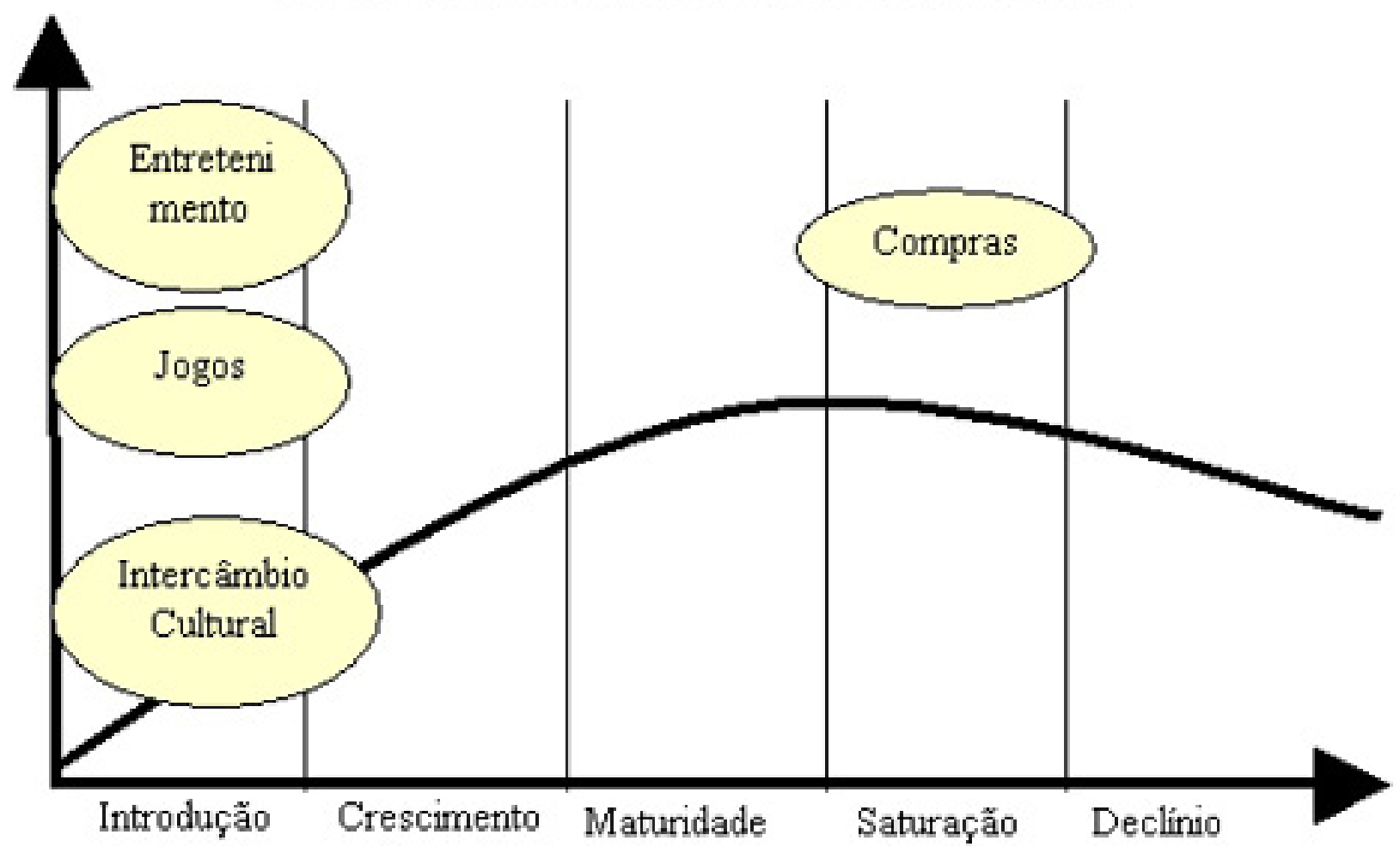

Fonte: Adaptado de D. Buhalis (2000) 


\section{Cenário Prospectivo}

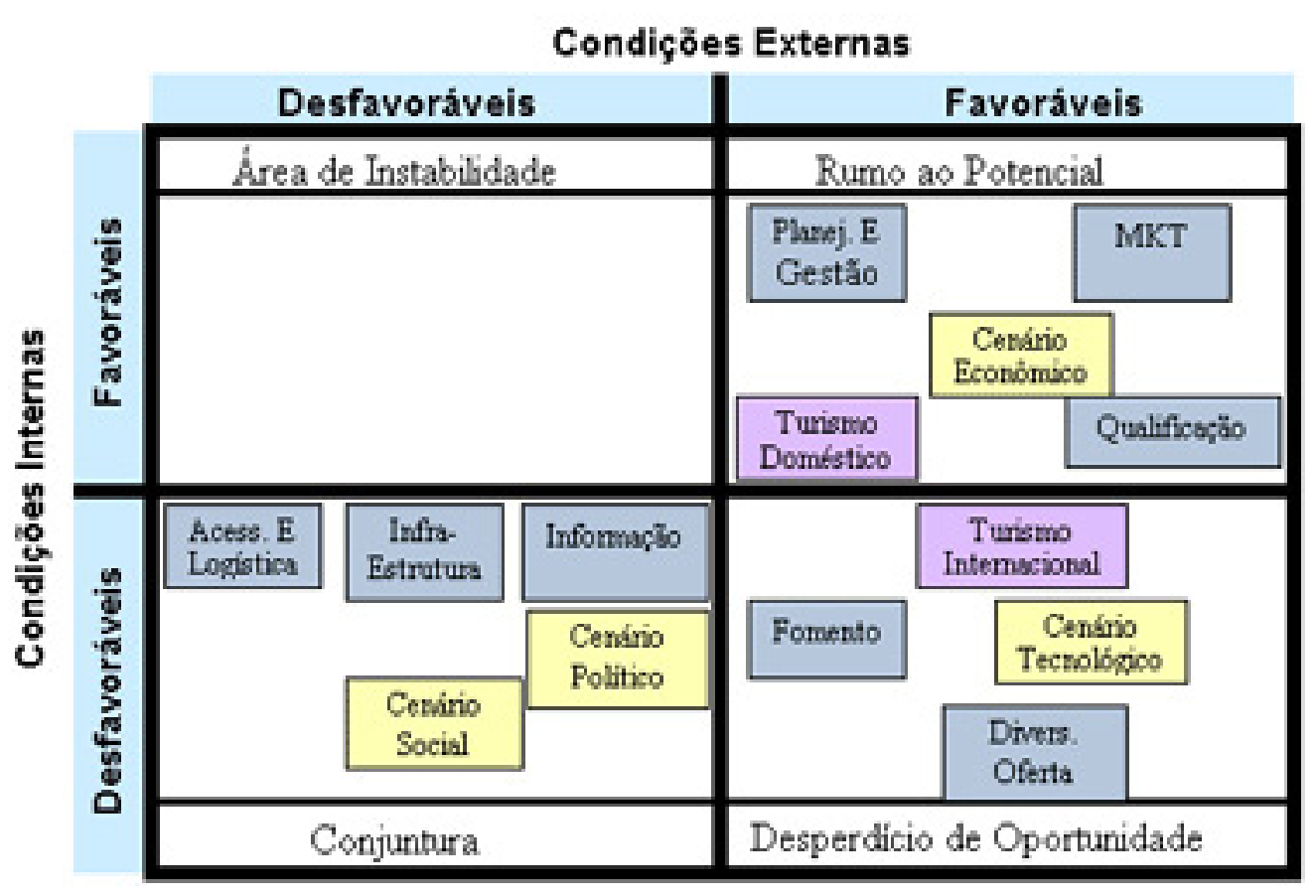

Fonte: Adaptado de Embratur (2006) - Livreto Turismo 
PROPOSTAS HIERARQUIZADAS ÁREAS ESTRATÉGICAS

Conforme dito anteriormente as propostas foram hierarquizadas após um debate estratégico/participativo onde os atores sociais envolvidos estiveram presentes definindo quais seriam suas prioridades e também quem seriam os órgãos/instituições responsáveis pela implementação das mesmas. Frisouse que tais atores já conheciam muitos dos problemas apresentados porém a falta de mensuração, acompanhamento e controle fez com que muitas das propostas que já haviam sido apresentadas continuassem sem serem implementadas. Por esse motivo frisou-se a importância da definição dos responsáveis. 


\section{PROPOSTAS GOVERNANÇA (PLANEJAMENTO/GESTÃO/FOMENTO/INFORMAÇÕES)}

\begin{tabular}{|c|c|c|}
\hline PROPOSTA & PRIORIDADE & RESPONSÁVEIS \\
\hline $\begin{array}{l}\text { Elaborar um estudo } \\
\text { para a criação de } \\
\text { uma estrutura de } \\
\text { governança capaz de } \\
\text { articular todos os atores } \\
\text { sociais em todas as fases } \\
\text { do processo }\end{array}$ & $1^{o}$ & $\begin{array}{l}\text { ESPECIALISTA - SMTU / } \\
\text { COMTUR / ICVB / Inst. } \\
\text { Caminhos do Turismo / } \\
\text { Gestur / SETU / Sebrae } \\
\text { - PR / Itaipu }\end{array}$ \\
\hline $\begin{array}{l}\text { Elaborar um estudo dos } \\
\text { impactos da atividade } \\
\text { turística no destino }\end{array}$ & $2^{o}$ & $\begin{array}{l}\text { Especialista / SETU } \\
\text { / Ipardes / SMTU / } \\
\text { Gestur / Universidades } \\
\text { / Itaipu / INST POLO } \\
\text { IGUASSU }\end{array}$ \\
\hline $\begin{array}{l}\text { Articular às iniciativas } \\
\text { pública e privada com } \\
\text { relação a investimentos } \\
\text { correntes e de capital } \\
\text { que beneficiem a } \\
\text { atividade turística }\end{array}$ & $3^{\circ}$ & $\begin{array}{l}\text { SMTUR / SETU / ICBV / } \\
\text { Comtur }\end{array}$ \\
\hline $\begin{array}{l}\text { Viabilizar fontes de } \\
\text { financiamento para } \\
\text { investimentos da } \\
\text { comunidade local }\end{array}$ & $4^{\circ}$ & $\begin{array}{l}\text { Instituicoes de Fomento } \\
\text { (bancos) / Comtur / } \\
\text { Agencia de fomento do } \\
\text { estado do PR / Sebrae / } \\
\text { Universidades }\end{array}$ \\
\hline $\begin{array}{l}\text { Elaborar um estudo } \\
\text { para captação de } \\
\text { forma estratégica de } \\
\text { investimentos externos }\end{array}$ & $5^{\circ}$ & $\begin{array}{l}\text { Especialista / SEBRAE / } \\
\text { ICVB / Gestur / Instituto } \\
\text { Caminhos / ACIF }\end{array}$ \\
\hline $\begin{array}{l}\text { Estreitar as relações do } \\
\text { segmento turístico com } \\
\text { os demais segmentos } \\
\text { econômicos da região }\end{array}$ & $6^{\circ}$ & $\begin{array}{l}\text { SMTU / COMTUR / ICVB } \\
\text { / Inst. Caminhos do } \\
\text { Turismo / Gestur / SETU } \\
\text { / Sebrae - PR / Inst Polo } \\
\text { Iguassu / Universidades } \\
\text { / Associacoes } \\
\text { comerciais da região }\end{array}$ \\
\hline
\end{tabular}




\section{PROPOSTAS QUALIDADE (QUALIFICAÇÃO/INFRA-ESTRUTURA)}

\begin{tabular}{|c|c|c|}
\hline PROPOSTA & PRIORIDADE & RESPONSÁVEIS \\
\hline $\begin{array}{l}\text { Implementar um } \\
\text { processo de gestão de } \\
\text { mudanças }\end{array}$ & $1^{\mathrm{o}}$ & $\begin{array}{l}\text { Especialista / Sebrae } \\
\text { / Gestur / Comtur / } \\
\text { Instituto / ICVB / Itaipu }\end{array}$ \\
\hline $\begin{array}{l}\text { Implementar o projeto } \\
\text { de qualificação com } \\
\text { foco em vendas e } \\
\text { marketing }\end{array}$ & $2^{o}$ & SMTU / Universidades \\
\hline $\begin{array}{l}\text { Viabilizar melhorias na } \\
\text { segurança pública. }\end{array}$ & $3^{\circ}$ & $\begin{array}{l}\text { SMTUR / Conselho } \\
\text { Municipal de Seguranca } \\
\text { / Orgaos de Seg. Publica } \\
\text { / COMTUR }\end{array}$ \\
\hline $\begin{array}{l}\text { Elaborar um estudo } \\
\text { para facilitar o } \\
\text { deslocamento na } \\
\text { cidade, na região e nos } \\
\text { três países }\end{array}$ & $4^{\circ}$ & $\begin{array}{l}\text { Especialista / SMTUR / } \\
\text { Relacoes Internacionais } \\
\text { / Universidade / ABAV / } \\
\text { Singetur / Coopertaxi / } \\
\text { Itaipu }\end{array}$ \\
\hline $\begin{array}{l}\text { Estudo das } \\
\text { necessidades } \\
\text { infra-estruturais } \\
\text { para viabilizar a } \\
\text { implementação das } \\
\text { propostas }\end{array}$ & $5^{\circ}$ & $\begin{array}{l}\text { Especialista - SETU } \\
\text { / Infraero / SMTU } \\
\text { / Secretaria Mun. } \\
\text { Planejamento / } \\
\text { COMTUR / ICVB }\end{array}$ \\
\hline $\begin{array}{l}\text { Elaborar um estudo } \\
\text { para implementação } \\
\text { de ações de } \\
\text { responsabilidade social } \\
\text { e ambiental do setor } \\
\text { turístico em relação à } \\
\text { comunidade local }\end{array}$ & $6^{\circ}$ & $\begin{array}{l}\text { SMTU / COMTUR / ICVB } \\
\text { / Inst. Caminhos do } \\
\text { Turismo / Gestur / SETU } \\
\text { / Sebrae - PR / Inst Polo } \\
\text { Iguassu / Universidades } \\
\text { / Associacoes } \\
\text { comerciais da região }\end{array}$ \\
\hline
\end{tabular}


PROPOSTAS MARKETING

(PROMOÇÃO/ESTRUTURAÇÃO/DIVERSIFICAÇÃO/LOGISTICA/INFORMAÇÕES)

\begin{tabular}{|c|c|c|}
\hline PROPOSTA & PRIORIDADE & RESPONSÁVEIS \\
\hline $\begin{array}{l}\text { Elaborar um Plano de } \\
\text { Marketing Estratégico }\end{array}$ & $1^{\mathrm{o}}$ & $\begin{array}{l}\text { Especialista - Comtur / } \\
\text { Sebrae / ICBV / Instituto } \\
\text { / Universidades / SMTU / } \\
\text { SETU / Singetur / Itaipu }\end{array}$ \\
\hline $\begin{array}{l}\text { Elaborar um estudo do } \\
\text { consumidor do destino } \\
\text { turístico }\end{array}$ & $2^{\circ}$ & $\begin{array}{l}\text { Especialista / SETU / } \\
\text { SMTU / Sebrae / ICVB / } \\
\text { Universidades / Instituto } \\
\text { / ABAV / Itaipu / Infraero }\end{array}$ \\
\hline $\begin{array}{l}\text { Elaborar um estudo } \\
\text { buscando resolver os } \\
\text { gargalos de acesso/ } \\
\text { distribuição. }\end{array}$ & $3^{\circ}$ & $\begin{array}{l}\text { Especialista / ABAV / } \\
\text { Universidades / Infraero } \\
\text { / Cia Aereas - COPET } \\
\text { / ATRIF / ABIH / ANAC } \\
\text { / SEBRAE / GESTUR / } \\
\text { COMTUR / ICVB }\end{array}$ \\
\hline $\begin{array}{l}\text { Elaborar um estudo } \\
\text { para a implantação de } \\
\text { um Citycard }\end{array}$ & $4^{\circ}$ & $\begin{array}{l}\text { Alguem que } \\
\text { possa desenvolver } \\
\text { estudoABAV / ICVB } \\
\text { / COMTUR / ABIH / } \\
\text { SEBRAE - PR / SMTUR / } \\
\text { Universidades / GESTUR } \\
\text { / Instituto / ACIF }\end{array}$ \\
\hline $\begin{array}{l}\text { Estudo para identificar } \\
\text { e fortalecer alianças } \\
\text { estratégicas com outros } \\
\text { destinos turísticos }\end{array}$ & $5^{\circ}$ & $\begin{array}{l}\text { Especialista - Comtur / } \\
\text { Sebrae / ICBV / Instituto } \\
\text { / Universidades / SMTU } \\
\text { / SETU / Singtur / Itaipu } \\
\text { / INFRAERO }\end{array}$ \\
\hline
\end{tabular}




\section{CONCLUSÃO}

O trabalho teve com intenção verificar algumas incertezas em relação ao turismo na região e a confirmação, ou não, de uma crise levantada pelo setor privado local. Após a análise dos documentos pode-se constatar que não há uma crise instaurada mas uma crise em potencial e o município de Foz do Iguaçu antevendo tal possibilidade buscou iniciar um trabalho de planejamento a médio e longo prazo.

Atualmente o pensamento de diversas localidades turísticas no Brasil está voltado para o curto prazo. Como o município de Foz do Iguaçu é internacionalmente conhecido da maneira com que a atividade vinha sendo desenvolvida até o momento estava de acordo com o pensamento de diversos atores sociais da região. No momento em que houve uma diminuição do fluxo de turistas, ocasionada em partes pela diminuição de ofertas de vôos para região e em partes pela diminuição do fluxo de águas das Cataratas em virtude da escassez da chuva, os atores sociais da região reviram seus conceitos verificando a necessidade de planejar a atividade de maneira estratégica para os próximos 10/20 anos com o intuito de serem menos suscetíveis a tais questões. O que ficou também claro é que é preciso haver uma sinergia entre a iniciativa pública, iniciativa privada e entidades de classe na região. Atualmente esta ligação é muito frágil e há uma necessidade de um trabalho em conjunto para uma soma de forças, pois o intuito de todos deveria ser o mesmo, o desenvolvimento sustentável do turismo na região.

Finalmente o que pode ser percebido é que muitos dos agentes envolvidos sabiam quais eram os problemas, inclusive já tendo propostas para solucionálos, porém com esta falta de integração entre os mesmos as propostas não eram exeqüíveis. Desta maneira ficou bastante claro que para que as propostas hierarquizadas pelos próprios agentes só seriam transformadas em ações caso houvesse o entendimento e participação de todos, estabelecendo, inclusive, responsáveis para cada uma das propostas. 


\section{REFERENNCIAS BIBLIOGRAFICAS}

- Bigné Alcañiz, J.; Font Aulet, X.; y Andreu Simó, L. (2000): Marketing de Destinos Turísticos: Análisis y Estrategias de Desarrollo. Madrid: Esic Editorial.

- Buhállis, D. (2000): The Tourism Destinations Life Cycle. Tourism Management $21,97-116$.

- Ejarque, J. (2003): Destinos Turísticos de Éxito - Diseño, Creación, Gestión y Marketing. Ediciones Pirámide, Madrid.

- Gil, J. (2004): Oportunidades y Amenazas de "La Cara Brasileña" para la Promoción Turística Internacional de Brasil en la "Sociedad de Ensueño". Disertação de Mestrado apresentada na Esculea Oficial de Turismo de la Universidad de Alicante - España.

- Jensen, R. (1999): The Dream Society - How the Comino Shift from Information to Imagination Hill Transform your Business. MacGrow Hill, New York.

- Kotler, P. (2000): Marketing para o Século XXI: Como Criar, Conquistar, e Dominar Mercados [ tradução Bazán Tecnologia e Lingüística]. Futura, São Paulo.

- Kotler, P.; Bowen, J. y Makens, J. (1997): Mercadotecnia para Hotelería y Turismo. Prentice Hall, Méjico.

- Lemos, L. (2005): O Valor Turístico na Economia da Sustentebilidade. Editora Aleph, São Paulo.

- Valls, J.-F (2000): Gestión de Destinos Turísticos Sostenibles. Ediciones Gestión 2000, Barcelona. 